\title{
Documentary evidence of historical floods and extreme rainfall events in Sweden 1400-1800
}

\author{
D. Retsö \\ Department of Economic History, Stockholm University, 10691 Stockholm, Sweden \\ Correspondence to: D. Retsö (dag.retso@ekohist.su.se)
}

Received: 25 June 2014 - Published in Hydrol. Earth Syst. Sci. Discuss.: 5 September 2014

Revised: 30 January 2015 - Accepted: 4 February 2015 - Published: 9 March 2015

\begin{abstract}
This article explores documentary evidence of floods and extreme rainfall events in Sweden in the preinstrumental period (1400-1800). The survey shows that two sub-periods can be considered as flood-rich, 1590-1670 and the early 18th century. The result related to a low degree of human impact on hydrology during the period, suggests that climatic factors, such as lower temperatures and increased precipitation connected to the so-called Little Ice Age rather than large-scale atmospheric circulation patterns, should be considered as the main driver behind flood frequency and magnitude.
\end{abstract}

\section{Introduction}

The purpose of this article is to give an overview of major historical flood events in Sweden in the pre-instrumental period (1400-1800) based on documentary sources. A few data concern Finland. Focus will be on river floods driven by rainfall (summer and autumn) and snowmelt (spring). First, a general presentation of the basic orographical and hydrological features of Sweden will be given, followed by a presentation and critical evaluation of available sources in terms of reliability and validity. An indexation on magnitude will be given and an attempt to identify flood-rich and flood-poor sub-periods will be made. A catalogue of floods and extreme rainfall events $1400-1800$ is found in Table A1, and a catalogue of possible flood-related harvest failures 1200-1600 is found in Table B1. The study intends to align with prevalent recommendations in methodology and observation periods in order to enhance the possibilities of synoptic reconstruction, calibration and general conclusions on flood regimes in Europe in the pre-instrumental period.

\section{Basic orographical and hydrological characteristics}

The Scandinavian mountain range (with a maximum altitude of $2469 \mathrm{~m}$ above sea level) runs in a north-south direction on the western side of the Scandinavian Peninsula. The continental divide largely coincides with the border between Sweden and Norway. Most rivers in Sweden flow down on the eastern slopes of the mountain range in a southeasterly direction through the largely flat lands into the Bothnian Sea and the Gulf of Bothnia. In south-central Sweden a number of large lakes are found - Vänern, Vättern, Mälaren and Hjälmaren - which catch waters to constitute the main basins of large catchment areas (see Fig. 1). In the southernmost part of the country the modestly elevated Småland highlands, with a maximum altitude of $377 \mathrm{~m}$, is the source of a number of smaller rivers that run both into the Baltic Sea to the east and the south and into the Kattegatt-Skagerrak of the North Sea in the west.

The most important catchment areas are Dalälven, Norrström, Göta älv and Motala ström (see Fig. 1). Dalälven is Sweden's longest river with a total extension of $520 \mathrm{~km}$. The total catchment area is $28954 \mathrm{~km}^{2}$. Lake Mälaren constitutes a basin collecting water from a wide range of smaller rivers, totalling a catchment area of $22650 \mathrm{~km}^{2}$, all flowing into the Baltic Sea at Stockholm. The main outlet is Norrström, north of the Old Town of Stockholm, which has given the name of the entire catchment area. Sweden's largest lake, Vänern, catches waters running down from the higher altitudes in the province of Värmland as well as in Norway and lets its waters continue to the North Sea by the Göta älv River. At its mouth, the second largest city of modern Sweden, Gothenburg, is located, though only founded as late as 1628. The total area of the catchment is $50229 \mathrm{~km}^{2}$. The Motala ström catchment area with $15481 \mathrm{~km}^{2}$, is constituted by 


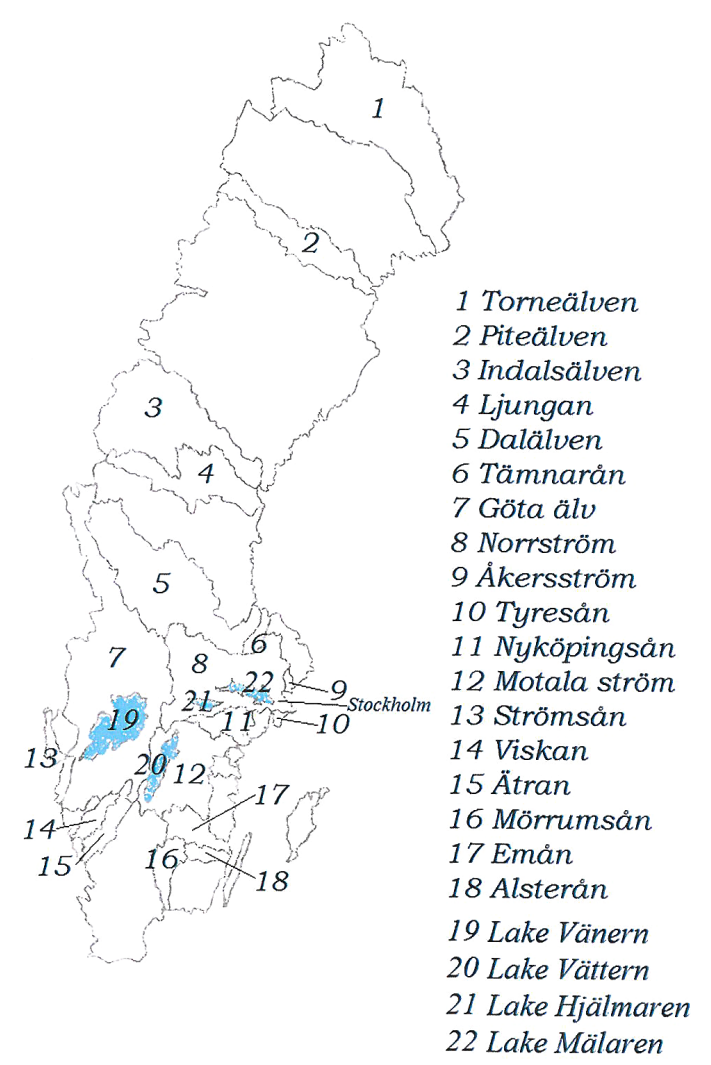

Figure 1. Catchment areas and major lakes in Sweden mentioned in the text.

the waters running from Lake Vättern to the Baltic Sea at Norrköping.

The geographical distribution of hydrological data in documentary sources mirrors the economic geography of medieval and early modern Sweden. Population density was highest in southern Sweden where consequently agriculture, the most important economic activity and especially sensitive to variations in hydrological patterns, was concentrated. Mining, the second most important economic activity, was concentrated in the less populated areas of Bergslagen in the provinces of Västmanland and Dalarna in the areas north and west of Lake Mälaren. Already in the Bronze Age rich mineral resources were found here, giving rise to an early mining activity which used the streaming rivers as a source of power for the roasting and smelting of the raw ore. The mining area predictably became an important zone for the Swedish economy. The rivers are often subject to intense spring floods when the snow in the mountains to the northwest melts rapidly. The seasonality of floods in the mining area is therefore concentrated to the spring season and is explained by a combination of snow storage in the mountains and the rate of melting in the spring. Lake Mälaren was originally a bay of the Baltic Sea but was separated from it and transformed into a lake by the continuous postglacial rebound around $1000 \mathrm{BC}$. The outlet was for long confined to
Södertälje and the two narrow canals Norrström and Söderström in Stockholm, founded around AD 1250 and later to become the capital of Sweden. The combination of these three factors - the importance of mining to the Swedish economy, the location of the mines near rivers subjected to spring floods and the location of Sweden's most prominent early city - produce a number of hydrological data in contemporary historical sources.

Although many catchment areas in Sweden are quite large $\left(15-50000 \mathrm{~km}^{2}\right)$, most rivers in south-central Sweden are, with a few exceptions, not suitable for navigation due to their small size and the presence of rapids. It led authorities at an early point to explore the possibilities of building canals and locks, but such projects were never carried out on any significant scale before the 19th century (Meyersson, 1943; Bring, 1911). Also dredging projects were few and limited before the 19th century. The only systematic dredging of Swedish rivers seems to have been a consequence of increased log driving, predominantly in the northern provinces and in the first half of the 18th century (Ahlbäck and Albertsson, 2006; Wik, 1950). Serious alterations of runoff through engineered modifications only occurred in the second half of the 20th century with the development of hydropower plants in the north. The hydrological events prior to the 19th century are therefore to a large extent the result of natural factors. The hydrologically most vulnerable point was the city of Stockholm. It is located at the outlet of Lake Mälaren, where a floodgate was constructed already before the 16th century to control the spring-flood water and where most works of this kind were carried out (see e.g. Almquist, 1903, 241 pp.; Handl. rör. Skand. hist. 19, 1834, 183 pp.; Almquist, 1913, p. 82). In the early 15 th century some dredging works were carried out at the outlet of Södertälje and again in the late 17th century but had little impact on the hydrology of the lake (Bring, 1924).

Consequently, the human impact on river streambeds and floodplains has been limited during the period in concern here. The pressure of urbanization, population increase, deforestation, and other land use changes as well as surface alterations and irregularities in channel alignment can be considered to be negligible due to the sparse population of Sweden and the low-intensity utilization of rivers. Hypothetically, climate, i. e. precipitation and temperature, would be the main driver behind any observable flood regime change before 1800 (Glaser et al., 2010; Wetter et al., 2011). Exceptionally, other natural factors than climate explain floods. For example, according to locals changes in the water levels of Lake Vänern were due to winds over the large lake surface rather than floods in the tributary rivers or drought (Elvius, 1751-1752, p. 39). 


\section{The documentary sources}

The present study has been mainly based on printed letters, diaries, travel notes, annals and chronicles, as well as secondary sources such as regional topographical descriptions. Some data have been found in the Swedish National Archives (Riksarkivet) in Stockholm. There are also some compilations of general weather data from the 18th century (Ferner, 1756; Falkengren, 1781; Ekman, 1783). Further data could still be found e.g. for the 18th century in newspapers but it is argued here that the main trends would not change substantially. The survey covers the period up to 1800, approximately a century before the beginning of systematic instrumental hydrographic measurements (Lindström and Alexandersson, 2004). The period has been chosen in order to avoid complications in the analysis due to the increased interference of anthropogenic factors in the 19th century.

As for most of Europe, the amount of documentary sources in Sweden is meagre for the Middle Ages but increases dramatically from ca. 1520 due to successful centralization efforts of the central authorities by King Gustavus Vasa (15231560) as well as fortunate preservation circumstances (Retsö and Söderberg, 2015a). Thus, for the 12th and 13th centuries, most climatological and parameteorological proxy data are found in chronicles and annals, written long after the events were described and most often of Danish or north German origin. This type of source material is notoriously difficult to use for historical reconstruction, but with specified methodology it is not useless especially concerning spectacular and severe events like floods (Wetter et al., 2011; Retsö and Söderberg, 2015b). Geographical specificity is not very great - in earlier sources it is confined to general terms (Sweden, Norway, Denmark). The earliest mentioning of a hydrological extreme found in Scandinavian sources possibly relevant for Sweden is from a Danish annal written sometime after 1288, which states that the year 1195 was characterized by "extreme wetness" (yuerwatis vadher) (Jørgensen, 1930 , p. 179). The only primary sources of a uniform kind from the Swedish Middle Ages are the diaries of the Birgittine monastery in Vadstena and the Franciscan order of Visby (Gejrot, 1996; Odelman and Melefors, 2008), but they contain very little of hydrological data.

The quantitative increase of documentary sources in general after 1520 also implies greater reliability since the number of independent data also increases and the basic requirements for documentary sources such as nearness in time and space and neutrality are better complied with, as well as the specific requirements on data for the study of long-term structures and parameteorological phenomena such as floods, namely, regularity, frequency, uniformity, high time resolution and geographical specificity (Bell and Ogilvie, 1978; Brázdil et al., 2005, 2010). In addition, the degree of detail as to the causes and impact on society is greater. There are several uniform individual records produced by the same person (e.g. Brahe, 1920; Hausen, 1880; Lewenhaupt, 1903), whole individual letter suites (e.g. Sjöberg, 1911, 1915; Wijkmark, 1995), and a number of institutional records such as letters from bailiffs and civil servants throughout the country (Retsö, 2002; Almquist 1868, 1875, 1877, 1893, 1902, 1903, 1913; Styffe, 1893; Edén, 1905; Ahnlund, 1930).

Hydrological data are limited to statements on extreme flood events or general characterizations of an entire year. The approach chosen here is the threshold approach (Hall et al., 2014), i.e. only floods and rainfall events that have been perceived by contemporaries to be beyond normality have been included. Concerning floods, the sources tell us about two cases: floods due to excessive precipitation and extreme spring floods. However, it is most often impossible to assess the magnitude of floods in quantitative terms. Some exceptions are the floods at Uppsala in 1622, at Söderköping in 1684 - for which the only known floodmark has been found (Broocman, 1760, p. 149) - at Holmen in 1646, at Ekby 1709, and at Stockholm and Uppsala in 1780.

The magnitude is normally described in vague qualitative terms, e.g. as the worst "in living memory" (mannaminne). It is argued here that such implicit comparisons with previous floods are indications of perceived absolute magnitude and not relative to real magnitude. The threshold approach inevitably involves an element of interpretation based on an analysis of terminology, the basic understanding of which may have varied somewhat over time and between persons but has nevertheless been mainly constant. For example, "severe spring flood" (svår vårflod) must have meant a spring flood above normal expectations, and the same is the case with "much wetness" (mycket väta).

The data used have thus been restricted to such data that can be confirmed to be reliable and valid and above the threshold of perceived normality. A commonly recommended 3-scale indexation of the magnitude is used here, based on the criteria of duration, spatial extension and material damage/human casualties (Sturm et al., 2001; Llasat et al., 2005; Glaser et al., 2010; Wetter et al., 2011): (1) floods on a regional scale with little material damage and/or short duration, (2) floods of significant regional or supra-regional magnitude with considerable material damage and/or average duration, and (3) floods of regional or supra-regional magnitude with disastrous material damage and/or long duration. Following Hall et al. (2014), the survey intends to identify flood-rich periods in order to facilitate cross-continental comparisons. Due to lack of reliable data at this stage no attempt will be made to assess discharge. All dates are adjusted according to the Gregorian calendar (New Style), introduced in Sweden in 1753.

\section{Results}

With all these prior observations of the source material, the result of the survey is as follows. A total of 157 floods or extreme rainfall events have been found for the period 1400 


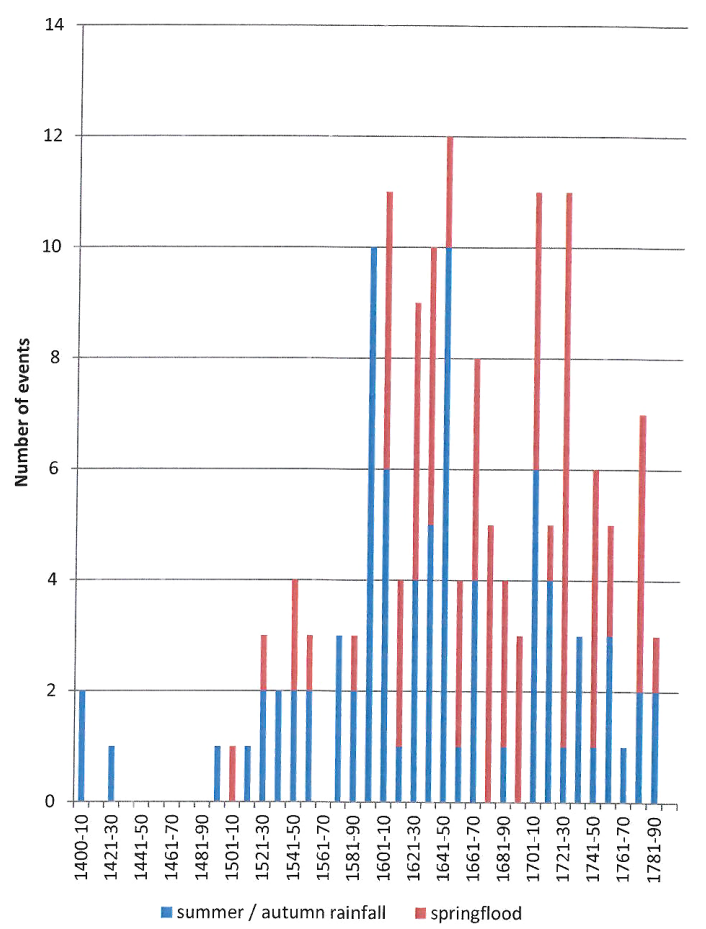

Figure 2. Decadal frequency of floods and extreme rainfall events in Sweden, 1400-1800, according to documentary sources.

1800, of which 107 can be unambiguously defined as floods (see Table A1). Catchments particularly hit by floods were Norrström, Göta älv and Dalälven (see Fig. 1).

There is no clear picture of flood frequency during this period. Yet, the data are clearly sufficient to make a preliminary identification of flood-rich and flood-poor periods (see Figs. 2 and 3). There is a clear tendency to more frequent floods in the 17th and 18th centuries in general. Especially two periods stand out as particularly flood-rich: 1591-1670 with two intermediate sub-periods with fewer floods in the 1610 s and the 1650 s, and the early 18 th century. On a decadal timescale the highest number of floods is found in the 1640s (12 events), the 1700s and the 1720s (11 each), followed by the 1630 s (10) and the 1620s (9). Years of significantly severe floods were 1649 (6 events), 1622 and 1780 (5 each), and 1596, 1640, 1661, 1677, 1707, 1709 and 1728 (4 each). Particularly serious was the flood in the province of Östergötland in August 1649 (the so-called Olsmässofloden). According to one assessment considerably more than $100 \mathrm{~mm}$, perhaps as much as $200-300 \mathrm{~mm}$ of rain may have fallen over certain locations in the southern and central parts of Östergötland in a few days (Alexandersson and Vedin, 2001). The flood in May 1650 seems to have been equally serious; the situation caused the authorities to initiate works to widen the outlet at Stockholm and also to investigate the possibilities to widen the outlet through the Södertälje Canal. The same happened in the spring of 1661 and the authorities sped up the work at Södertälje (Bring, 1924, p. 16).

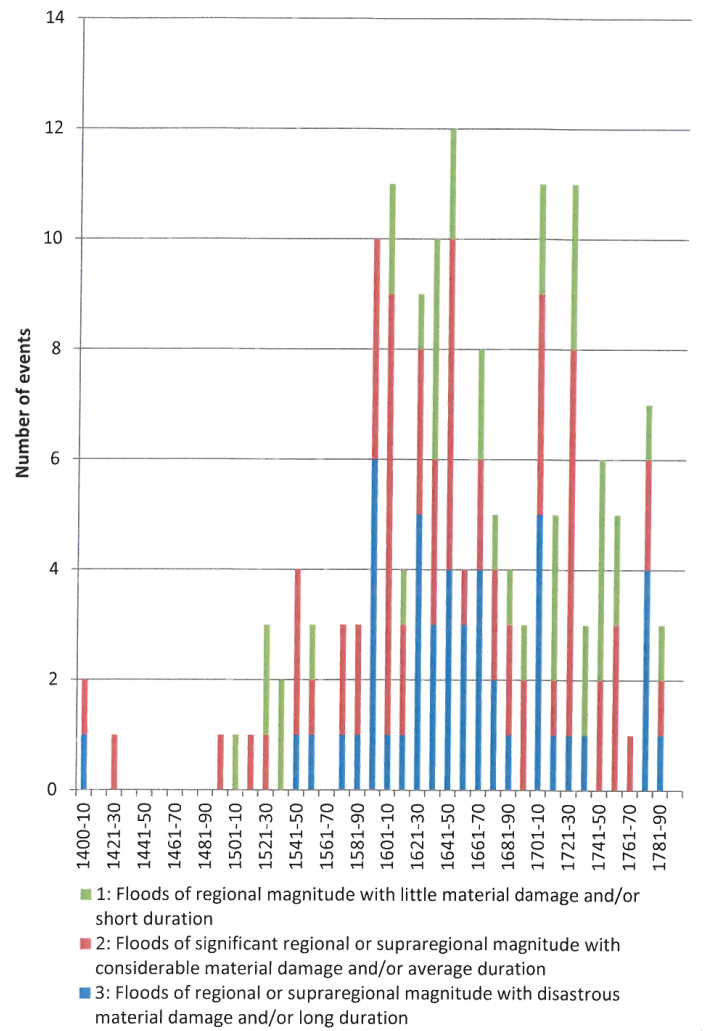

Figure 3. Documentary evidence of floods and extreme rainfall events in Sweden, 1400-1800, with levels of magnitude.

As for magnitude, $32 \%$ of all events were of the third category (floods of regional or supraregional magnitude with disastrous material damage and/or long duration), and $44 \%$ of the second category (floods of significant regional or supraregional magnitude with considerable material damage and/or average duration) (Fig. 3). The impression of the period $1591-1670$ as one of dramatic hydrology is substantiated by the fact that almost one-sixth, or 27, of all third category events occurred during that period.

\section{Discussion}

\subsection{Comparison with flood-rich and flood-poor periods in continental Europe}

The result does not neatly coincide nor with tendencies in flood frequency or particular events observed in continental Europe (compare e.g. Wetter et al., 2011; Benito et al., 2003; Glaser et al., 2010; Glaser and Stangl, 2004; Elleder, 2013; De Kraker, 2006). For example, both Brázdil et al. (1999) and Schmocker-Fackel and Naef (2010) found few floods in northern Switzerland in the first half of the 16th century but there was a flood frequency peak in 1560-1590, whereas a first peak in Sweden is found only in the following 2 decades. As for the 17th century, there was a low in Switzer- 
land until the first decades of the 18th century (Pfister, 1999; Schmocker-Fackel and Naef, 2010). The latter half of the century was again a period of high frequency, which only partially coincides with the documentary data from Sweden. There are no traces of similarities with Sweden on single extreme years in the same region (Wetter et al., 2011) or in central Europe at a larger scale (Glaser et al., 2010). There are only slight similarities with the flood chronology of Spain, in particular for the Llobregat and Tagus catchments in the extended period 1580-1620 (Llasat et al., 2005; Benito et al., 2003).

\subsection{Relation to quantity of source data}

The first question to address is whether this can be explained by a deficiency in the Swedish source material. It is held here that more documentary sources could doubtlessly improve the picture in its details but not substantially change the general pattern. For example, the increase in reliable flood data in the 17th and 18th centuries is not entirely a reflection of a total increase in documentary sources. Indeed, the total quantity of preserved documentary sources rises considerably already in the 1520s but the rising frequency of floods does not occur until the 1590s. It can thus be concluded that the data most probably reflect a real increase in flood events towards the late 16th century. Consequently, it can also be presumed that floods really were more rare in the source-poor late Middle Ages. As has been pointed out by Wetter et al. (2011), it is highly improbable that spectacular events like major floods would pass unnoticed by chroniclers.

\subsection{Comparison with North Atlantic Oscillation (NAO) reconstructions}

The meteorological/climatological causes behind these Swedish flood data require further research to be identified. In a number of studies the great variability in flood frequencies in Europe has been explained by large-scale atmospheric circulation patterns, particularly on a decadal timescale (Schmocker-Fackel and Naef, 2010; Casanueva et al., 2014). In particular, the NAO together with other, related atmospheric circulation patterns is normally seen as the main explanation for climatic variability in northern Europe (Lindholm et al., 2009), especially winter precipitation in the NAO positive phases (Hurrell and Van Loon, 1997; Barker et al., 2004; Casanueva et al., 2014) as well as for river discharges, snow accumulation and flooding (Prudhomme and Genevier, 2011).

However, there is no clear connection between the existing NAO reconstructions and flood frequency in Sweden. In one reconstruction (Luterbacher et al., 1999) a few winter NAO indices coincide with flood peaks in Sweden (early 18th century, the 1770s and perhaps also the 1740s), while in others the picture is somewhat different (see e.g. Luterbacher et al., 2002; Glueck and Stockton, 2001). For example, while it would seem that a tendency to a 10-12 years cycle, a timescale which is close to one of the suggested NAOs (Hurrell and Van Loon, 1997; Cook et al., 1998), could be seen in the Swedish sources between 1620 and 1661 there is no sign of it after that. Similarly, one NAO winter index reconstruction (Cook et al., 2002) identifies a positive phase until about 1640 whereafter it went into a neutral or negative phase which would not be able to explain the flood peaks in Sweden in the following decades. If the chronology of Swedish flood events is compared with the NAO index found in Luterbacher et al. (2002), then no correlation at all can be seen. According to expectations, the NAO would have a marked influence on precipitation and streamflow, particularly in its positive mode when westerly winds bring moist and warm air over Scandinavia. NAO is also expected to have a stronger effect in the winter than in the summer, and a stronger effect in northern Sweden than in the south (Uvo, 2003). However, the documented floods are slightly more frequent in negative NAO phases (83 events) than in positive NAO phases (64 events). Furthermore, floods related to the winter season, i.e. spring floods, are about as many (70) as those related to the summer season (77). There is no clear tendency in either high altitude or high latitude catchments (defined as catchments no. 1-5 and 7-8 in Fig. 1): the number of events (106) in the former catchments is indeed greater than the number of events (34) in the low latitude/altitude catchments but exhibits a perfectly equal distribution between positive and negative NAO phases (53 events each).

Previous attempts have failed to establish an unambiguous connection between NAO, winter precipitation and floods, in general, particularly for northern Europe (Bouwer et al., 2006; Uvo, 2003; Casty et al., 2005). One reason for that is undoubtedly that NAO operates on a great variety of timescales and is interfered with by other local conditions as well as other circulation patterns (Jacobeit et al., 2003; Lavers et al., 2012). Also changes in flood frequencies are obviously the result of the workings of several driving forces at the same time but to different degrees at different times and places, particularly in colder climates as in Sweden. For example, it seems that NAO-related precipitation patterns east of the Scandinavian mountains, i.e. in Sweden, are overplayed by other climatic factors (Uvo, 2003; Linderholm et al., 2003). However, it is conspicuous that the great majority of the worst flood events have been recorded in catchments that are particularly subjected to spring floods fuelled by melting snow from high altitudes or latitudes (Norrström, Göta älv, Dalälven, Torneälven, Piteälven, Ljungan, Indalsälven) and where lake evapotranspiration is lower and water storage capacity higher (see Fig. 1). Furthermore, if the average winter temperature of Stockholm (Leijonhufvud et al., 2010) is taken as a proxy for a general meteorological pattern in southern and central Sweden, the frequency of floods has a clear correlation with cold and snowy winters. Although the correlation of winter precipitation with NAO is generally weaker in Sweden than on the Atlantic coast of Norway 
(Uvo, 2003) and although temperature tends to increase under positive NAO, precipitation in the winter at northern latitudes would under all conditions and NAO modes come as snow and therefore generate a larger storage of water in the mountains. Thus, the melting of large amounts of snow in the spring would affect Sweden as well and thereby contribute to spring floods whose intensity would depend on the evolution of temperature in the spring.

Plausibly, a decline in evaporation due to decreasing mean temperatures, probably in connection with heavy winter precipitation in the form of snow and increased spring precipitation due to NAO, generated considerably higher levels of runoff, notably at higher altitudes (cf. Burt and Howden, 2013) where the wellsprings of most Swedish catchments are located. The combination of soil saturation, huge snow amounts and spring rain has been pointed out a an important trigger for spring floods (Wetter et al., 2011). This allows for the conclusion that the NAO can account for precipitation patterns, mainly in the winter, but not necessarily all flood peaks, whereas climate plays the main role for the frequency of floods. The peaks in Sweden's flood history would then be characterized as cases of "complex extremes" (Benestad and Haugen, 2007), involving both temperature and precipitation. In some cases, the correlation between snow-rich winters and spring floods is explicit in contemporary sources; for example, the winters of $1543,1544,1601$ and 1780 and the following disastrous spring floods. This correlation between flood frequencies and the so-called Little Ice Age has also been noted for other areas of Europe (Brázdil et al., 1999; Pfister, 1999; Glaser, 2008).

\subsection{Medieval floods and harvest failures without stated causes}

There are no unambiguously reliable data on floods in Swedish medieval sources before the 15th century. In Danish and German chronicles reports are found of heavy raining and/or floods in 1287, 1315, 1336, 1347, 1357 and 1381 that could possibly have affected Sweden (Holder-Egger, 1880, p. 546; Rørdam, 1873, p. 318, 589, 592 pp.; Langebek, 1772, p. 303; Langebek and Suhm, 1786, p. 532), but the only indication in Swedish sources is a blunt general statement about "evil and wet weather" in 1313 in the Erik chronicle, written in the 1330s (Jansson, 2003, p. 148). It should be noted that there are no indications in Swedish medieval sources, as in central Europe, for floods in the 1340s or in 1501 (cf. Rokoengen et al., 2001; Brázdil et al., 2005; Rohr, 2007; Kiss, 2009; Elleder et al., 2013). It is also uncertain whether the statements in Danish chronicles are relevant for Sweden. The same is the case with the report in Heinrich of Balsee's chronicle on a flood in northern Germany in December 1374 (Crull, 1878, 165 pp.).

In many cases the magnitude of floods in the early modern period is related to the damage on crops (see e.g. Jämtl. räk., 1564-1571, 38 pp.; Sommarström, 1935, p. 285; Ekström,
1949, p. 417; Lindblom, 1793, p. 121; Strömbeck, 1993, p. 170). Some medieval data tell about severe harvest failures and famine without stating the causes (see Table B1). At the present stage no details can be found to support that these extreme events were caused by floods and undoubtedly some of them are connected to drought. But it is also clear that several of them may have been caused by floods. Already Emmanuel Le Roy Ladurie warned about the difficulty to establish a strict causal connection between climate and crop failures unless the precise cause is stated or the data can be supported by other contemporary data (Le Roy Ladurie, 1971, 275-6 pp.). The purpose of presenting the Swedish data here is to furnish a point of departure for future research and comparative analyses that can shed more light on the matter.

\section{Conclusions}

Two periods stand out as particularly flood-rich in the preinstrumental period in Sweden according to documentary records: $1591-1670$ and the early 18 th century. In particular, there are clusters of floods in the 1640s, the 1700s and the 1720s. One-third of all events were floods of regional or supra-regional magnitude with disastrous material damage and/or long duration, and half of them occurred in the period 1591-1670.

The spatial scale of spring floods and their temporal concentration in clusters suggest causality on a large timescale, i.e. meteorological conditions connected with the Little Ice Age rather than atmospheric circulation patterns such as the North Atlantic Oscillation (NAO) and a reflection of regional response to climatic variability. NAO could very well explain winter precipitation patterns as well as the flood peaks between 1591 and 1650 but only in combination with a Little Ice Age cooling, which in turn is the more plausible explanation for the peaks in the early 18th century. Given the high degree of continuity in demographic and economic conditions in the 1400-1800 period, it therefore seems reasonable to conclude that among the potential drivers of flood regime change are the changes in precipitation and temperature, i.e. climatic change, that mainly account for the longterm variability of historical floods in this period. Although there is a natural time lag in relation to temperature, there is a clear correlation between the seasonality and the chronology of spring floods, on the one hand, and, on the other, rapid and late melting of larger snow storages in combination with spring precipitation from ca. 1600. This is further confirmed by the observable spatial coherence of major flood events. 


\section{Appendix A}

Table A1. Documentary evidence of floods and extreme rainfall events in Sweden 1400-1800 (bf - before).

\begin{tabular}{|c|c|c|c|c|c|c|c|c|}
\hline Year & Date & Location & River & Catchment & Index & Type & Source & Comment \\
\hline 1400 & after 26 July & Söderköping & Storån & Storån & 2 & rainfall & $\begin{array}{l}\text { Fant (1818) p. } 95 \\
\text { Paulsson (1974) p. } 289 \\
398 \text { pp. }\end{array}$ & $\begin{array}{l}\text { great flood caused by sudden, violent raining; } \\
\text { people fled the town in fear of a Deluge; knee- } \\
\text { high water inundated cemeteries and streets; } \\
\text { bridges and mills destroyed }\end{array}$ \\
\hline 1405 & 7 August & (Denmark, Sweden) & - & - & 3 & rainfall & Rørdam (1873) p. 555 & $\begin{array}{l}\text { continuous raining from early August to } \\
\text { Christmas }\end{array}$ \\
\hline 1421 & summer & Vadstena & Lake Vättern & Motala ström & 2 & rainfall & Gejrot (1996) p. 174f & $\begin{array}{l}\text { "so great quantities of rain that corn rotted ... } \\
\text { followed by plague" }\end{array}$ \\
\hline 1495 & 7 November & Stockholm & (Norrström) & Norrström & 2 & rainfall, sea flood & Fant (1818) p. 68 & $\begin{array}{l}\text { great storm and sea flood destroyed several ships } \\
\text { in the harbour }\end{array}$ \\
\hline 1506 & April & Arboga & Arbogaån & Norrström & 1 & snowmelt & Sjödin (1937) p. 205 & $\begin{array}{l}\text { unusually great spring flood, "a thousand men } \\
\text { could not go against it" }\end{array}$ \\
\hline 1513 & July & (Sweden) & - & - & 2 & rainfall & Retsö (2002) p. 148 & the greatest rainfall in $6-8$ years \\
\hline 1523 & January & Markaryd & & & 1 & snowmelt & Larsson (2002) p. $69 \mathrm{f}$ & great inundations hindered warfare \\
\hline 1526 & autumn & $\begin{array}{l}\text { Västergötland } \\
\text { Province }\end{array}$ & - & Göta älv & 1 & rainfall & Almquist (1868) 74 pp. & much rain and wetness \\
\hline 1530 & summer & Uppsala bishopric & NA & Norrström & 2 & rainfall & Almquist (1877) p. 207 & very wet summer and autumn, crops endangered \\
\hline 1533 & 5 August & Sala & NA & Norrström & 1 & rainfall & $\begin{array}{l}\text { Riksarkivet, } \\
\text { Kammararkivet, } \\
\text { Bergsbruk, Sala gruva } \\
\text { 1533-1537 }\end{array}$ & $\begin{array}{l}\text { great torrential rain, miners refused to enter the } \\
\text { mines due to the excessive water }\end{array}$ \\
\hline 1534 & 8 September & Sala & NA & Norrström & 1 & rainfall & $\begin{array}{l}\text { Riksarkivet, } \\
\text { Kammararkivet, } \\
\text { Bergsbruk, Sala gruva } \\
\text { 1533-1537 }\end{array}$ & $\begin{array}{l}\text { great torrential rain, miners refused to enter the } \\
\text { mines due to the excessive water }\end{array}$ \\
\hline 1543 & summer & (Sweden) & - & - & 2 & rainfall & Ekman (1783) p. 143 & very wet and cold summer \\
\hline 1544 & summer & (Sweden) & - & - & 2 & rainfall & $\begin{array}{l}\text { Forssell (1884) Appendix A } \\
\text { p. } 157\end{array}$ & very wet and cold summer \\
\hline 1549 & 23 April & Uppsala & Fyrisån & Norrström & 2 & snowmelt & Almquist (1902) 13/4 1549 & spring flood flushed away a mill dam \\
\hline 1550 & bf 21 May & Lake Mälaren & - & Norrström & 3 & snowmelt & $\begin{array}{l}\text { Almquist (1903) } 241 \text { pp., } \\
\text { Handl. rör. Skand. hist. } \\
19 \text { pp., } 183 \text { pp. }\end{array}$ & $\begin{array}{l}\text { great spring flood causing "mighty great damages } \\
\text { on fields and meadows" }\end{array}$ \\
\hline 1557 & bf 15 May & Lake Mälaren & - & Norrström & 3 & snowmelt & Almquist (1913) p. 82 & $\begin{array}{l}\text { great spring flood and rapidly rising water levels } \\
\text { due to large quantities of ice and snow melting } \\
\text { causing great damages on meadows, dams, } \\
\text { bridges and mills }\end{array}$ \\
\hline 1559 & July & $\begin{array}{l}\text { (Västmanland } \\
\text { Province) }\end{array}$ & - & Norrström & 2 & rainfall & Dalin (1760-1761) p. 485 & great rainfall; all hay flushed away \\
\hline 1560 & 9 July & Arboga & Arbogaån & Norrström & 1 & $\begin{array}{l}\text { torrential } \\
\text { rain }\end{array}$ & Ekström (1949) p. 265 & $\begin{array}{l}\text { sudden torrential rain causing such a darkness that } \\
\text { the priest needed a light in the middle of the day } \\
\text { and people thought Doomsday was at hand }\end{array}$ \\
\hline 1571 & summer & Ragunda & Indalsälven & Indalsälven & 2 & rainfall & $\begin{array}{l}\text { Jämtl. räk. (1564-1571) } \\
38 \text { pp. }\end{array}$ & small harvest due to great wetness \\
\hline 1573 & summer & Linköping & & Motala ström & 3 & rainfall & Granlund (1876) p. 45 & the cathedral at Linköping damaged by rain \\
\hline 1580 & summer & $\begin{array}{l}\text { (south Västergötland } \\
\text { Province) }\end{array}$ & $\begin{array}{l}\text { Viskan, } \\
\text { Ätran }\end{array}$ & Viskan, Ätran & 2 & rainfall & Österberg (1971) p. 219 & "terrible wetness", peasants unable to pay taxes \\
\hline 1581 & spring & Gliehammaren & - & Norrström & 2 & snowmelt & $\begin{array}{l}\text { Noraskogs arkiv } \\
(1889-1891) \text { p. } 173\end{array}$ & water wheel damaged beyond repair \\
\hline 1589 & autumn & Skerike & Svartån & Norrström & 3 & rainfall & Ekström (1949) p. 78 & great wetness destroyed the crops \\
\hline 1589 & summer & Romfartuna & Lillån & Norrström & 2 & rainfall & Ekström (1949) p. 663 & damages on crops due to wetness \\
\hline 1595 & bf 7 July & Finland & - & - & 2 & rainfall & Sommarström (1935) p. 285 & bad harvest and rotten hay due to excessive rains \\
\hline 1595 & summer & (Sweden) & - & - & 2 & rainfall & Brahe (1920), p. 15 & unprecedented extreme rains \\
\hline 1596 & 10 August & Örslösa & Söneån & Göta älv & 3 & rainfall & $\begin{array}{l}\text { Silvén-Garnert and } \\
\text { Söderlind (1980) p. } 158 \mathrm{f}\end{array}$ & $\begin{array}{l}\text { great deluge-like rainfall, flushing away bridges, } \\
\text { water covering fields and meadows destroying } \\
\text { crops and killing goats and sheep }\end{array}$ \\
\hline 1596 & ca. 25 June-ca. 25 July & $\begin{array}{l}\text { (northern } \\
\text { Södermanland } \\
\text { Province) }\end{array}$ & - & Norrström & 2 & rainfall & Lewenhaupt (1903) p. 109 & raining almost every day for 1 month \\
\hline 1596 & summer & Orsa & Oreälven & Dalälven & 3 & rainfall & Ekström (1949) p. 417 & "severe wetness destroyed the harvest" \\
\hline
\end{tabular}


Table A1. Continued.

\begin{tabular}{|c|c|c|c|c|c|c|c|c|}
\hline Year & Date & Location & River & Catchment & Index & Type & Source & Comment \\
\hline 1596 & July & Lönneberga, Ålem & $\begin{array}{l}\text { Silverån, } \\
\text { Alsterån }\end{array}$ & $\begin{array}{l}\text { Emån, } \\
\text { Alsterån }\end{array}$ & 3 & rainfall & $\begin{array}{l}\text { Hallendorff (1902) p. } 77 \\
\text { Edman (1985) p. } 72\end{array}$ & $\begin{array}{l}\text { flood caused by heavy rainfall; all meadows } \\
\text { covered by water so that they looked like lakes; } \\
\text { bad damages on hay and corn crops, and animals } \\
\text { died of food shortage, hay flushed away from } \\
\text { meadows and the crop failure created hunger } \\
\text { among peasants }\end{array}$ \\
\hline 1597 & 22 May & Ålem & Alsterån & Alsterån & 3 & torrential rain & Edman (1985) p. 72 & $\begin{array}{l}\text { torrential rain brought by northerly winds; all } \\
\text { crops flushed away and the fields looked like } \\
\text { lakes }\end{array}$ \\
\hline 1597 & 27 June & Ålem & Alsterån & Alsterån & 3 & torrential rain & Edman (1985) p. 72 & $\begin{array}{l}\text { torrential rain for } 24 \text { hours; corn plants drowned } \\
\text { in water and crops flushed away }\end{array}$ \\
\hline 1600 & summer & $\begin{array}{l}\text { (Östergötland } \\
\text { Province) }\end{array}$ & - & - & 2 & rainfall & Wennberg (1947) p. 197 no. 3 & crops partly destroyed by wetness \\
\hline 1600 & $\begin{array}{l}20 \text { September- } \\
10 \text { October }\end{array}$ & Ålem & Alsterån & Alsterån & 3 & rainfall & Lindblom (1793) p. 121 & $\begin{array}{l}\text { continuous raining for } 3 \text { weeks from } \\
20 \text { September, harvests ruined }\end{array}$ \\
\hline 1601 & April & Ålem & Alsterån & Alsterån & 3 & snowmelt & $\begin{array}{l}\text { Edman (1985) p. } 75 \\
\text { Collmar (1960) p. } 85 \\
\text { Utterström (1955) p. } 29\end{array}$ & $\begin{array}{l}\text { great spring flood caused by sudden warmth } \\
\text { following a severe winter with much snow; all } \\
\text { bridges and most mills destroyed, next year's } \\
\text { seeds destroyed }\end{array}$ \\
\hline 1602 & summer & Fresta, Hammarby & - & Norrström & 2 & rainfall & Strömbeck (1993) p. 170 & excessive rains destroyed most of the harvest \\
\hline 1602 & $\begin{array}{l}\text { summer, } \\
\text { autumn }\end{array}$ & Ålem & Alsterån & Alsterån & 2 & rainfall & $\begin{array}{l}\text { Edman (1985) p. } 76, \\
\text { Collmar (1960) p. } 85, \\
\text { Palme (1942) p. } 391\end{array}$ & $\begin{array}{l}\text { "mighty severe autumn wetness" damaged hay } \\
\text { crops and other crops }\end{array}$ \\
\hline 1603 & bf 25 February & $\begin{array}{l}\text { Kumogård, Birkkala } \\
\text { (Finland) }\end{array}$ & Kumo älv & Kumo älv & 1 & snowmelt & Waaranen (1864) 9, $12 \mathrm{pp}$. & $\begin{array}{l}\text { "superfluous water", "waterflow and unnatural } \\
\text { wetness" }\end{array}$ \\
\hline 1604 & spring & Nykroppa & Kroppaälven & Göta älv & 2 & snowmelt & Furuskog (1924) p. 80 & $\begin{array}{l}\text { water dams busted by spring flood, requiring } \\
354 \text { days of work to repair }\end{array}$ \\
\hline 1606 & spring & Lillfors & Storfors-älven & Göta älv & 2 & snowmelt & Furuskog (1924) p. 83 & $\begin{array}{l}\text { water dam busted by spring flood; it took } 4 \\
\text { weeks to repair it }\end{array}$ \\
\hline 1607 & autumn & Ålem & Alsterån & Alsterån & 2 & rainfall & Edman (1985) p. 84 & "extreme autumn wetness" \\
\hline 1608 & May & Ålem & Alsterån & Alsterån & 2 & rainfall & Edman (1985) p. 84 & $\begin{array}{l}\text { "two mighty great waterfloods in May and in } \\
\text { August" with much damages on hay and corn } \\
\text { crops }\end{array}$ \\
\hline 1608 & August & Ålem & Alsterån & Alsterån & 2 & rainfall & Edman (1985) p. 84 & $\begin{array}{l}\text { "two mighty great waterfloods in May and in } \\
\text { August" with damages on hay and corn }\end{array}$ \\
\hline 1610 & 16-18 March & Visby, Gotland & - & - & 2 & rainfall & Strelow (1633) p. 298 & "severe flood", water high in the streets \\
\hline 1610 & spring & (Sweden) & - & - & 1 & snowmelt & Ekman (1783) p. 149 & great waterflood \\
\hline 1613 & spring & (Dalarna Province) & - & Dalälven & 1 & snowmelt & Sillén (1865) p. 84 & "strong waterflow" \\
\hline 1614 & autumn & Växjö & - & Mörrumsån & 2 & rainfall & Ahnlund (1930) p. 363 & harvest "badly damaged" by rain \\
\hline 1617 & spring & Kuivakangas & Torne älv & Torne älv & 3 & snowmelt & $\begin{array}{l}\text { Olofsson and Stille } \\
\text { (1965) p. } 213\end{array}$ & $\begin{array}{l}\text { The Särkilax chapel floated away with the } \\
\text { spring flood }\end{array}$ \\
\hline 1618 & spring & Uppsala & Fyrisån & Norrström & 2 & snowmelt & Falkengren (1781) & "much damage" by spring flood \\
\hline 1622 & spring & Löfsta, Uppsala & Fyrisån & Norrström & 3 & snowmelt & $\begin{array}{l}\text { Swederus (1911) p. 238, } \\
\text { Falkengren (1781) }\end{array}$ & $\begin{array}{l}\text { dams damaged at the Löfsta mill and in Uppsala } \\
\text { town, ice blocks thrown up on the main square }\end{array}$ \\
\hline 1622 & spring & Norrköping & $\begin{array}{l}\text { Norrköpings } \\
\text { ström }\end{array}$ & Motala ström & 3 & snowmelt & Helmfrid (1959) p. 21 & all water dams swept away by the spring flood \\
\hline 1622 & spring & Piteå & Pite älv & Pite älv & 3 & snowmelt & $\begin{array}{l}\text { Olofsson and Stille } \\
\text { (1965) p. } 273\end{array}$ & dams at Piteå sawmill damaged \\
\hline 1622 & 1 August & Stockholm & - & Norrström & 2 & rainfall & Ahnlund (1920) p. 40f & much rain, breaking down the corn \\
\hline 1622 & bf 28 October & Gothenburg & Göta älv & Göta älv & 2 & rainfall & Cronholm (1864) p. 67 & the harbour damaged by much rain \\
\hline 1623 & ca. 30 June & eastern Värmland & - & Göta älv & 2 & rainfall & Hausen (1880) p. 270 & $\begin{array}{l}\text { a statement on a severe spring flood in } 1663 \text { says } \\
\text { that an equally destructive flood took place } \\
40 \text { years earlier }\end{array}$ \\
\hline 1625 & $\begin{array}{l}\text { bf } 5 \text { April- } \\
10 \text { May }\end{array}$ & Säter & Dalälven & Dalälven & 3 & snowmelt & $\begin{array}{l}\text { Edén (1905) } 206 \text { pp., } \\
\text { Wittrock (1919) p. 57, } \\
\text { Wolontis (1936) p. 63, } \\
\text { Falkengren (1781) }\end{array}$ & $\begin{array}{l}\text { spring flood unusually violent, destroying the mint } \\
\text { at Säter on } 10 \text { May, nine people went missing }\end{array}$ \\
\hline 1626 & bf 28 April & Nyköping & Nyköpings-ån & Nyköpingsån & 1 & snowmelt & Wittrock (1919) p. 74f & the copper minting hindered by spring flood \\
\hline 1628 & summer & (Sweden) & - & - & 3 & rainfall & $\begin{array}{l}\text { Ekman (1783) p. 136, } \\
\text { Falkengren (1781) }\end{array}$ & $\begin{array}{l}\text { very rainy summer, flooded fields and meadows, } \\
\text { damaged harvests }\end{array}$ \\
\hline 1632 & bf 28 October & Stockholm & (Norrström) & Norrström & 1 & rainfall & Styffe (1893) p. 504 & "continuous wetness" \\
\hline 1632 & summer & Öland & - & - & 1 & rainfall & $\begin{array}{l}\text { Ilmoni (1849) p. } 185 \text {, } \\
\text { Sillén (1865) p. } 84, \\
\text { Ahlqvist (1825) p. } 295\end{array}$ & continuous raining \\
\hline
\end{tabular}


Table A1. Continued.

\begin{tabular}{|c|c|c|c|c|c|c|c|c|}
\hline Year & Date & Location & River & Catchment & Index & Type & Source & Comment \\
\hline 1632 & July & northern Sweden & - & - & 1 & rainfall & $\begin{array}{l}\text { Olofsson and Stille } \\
\text { (1965) p. } 311\end{array}$ & cold and wet \\
\hline 1633 & summer & Öland & - & - & 2 & rainfall & Sillén (1865) p. 84 & continuous raining, famine and dear times \\
\hline 1633 & summer & (Sweden) & - & - & 3 & rainfall & Ekman (1783) p. 136 & $\begin{array}{l}\text { rainy summer with poor harvests in the south and } \\
\text { harvest failures in the north }\end{array}$ \\
\hline 1638 & spring & Västerbotten & - & - & 3 & $\begin{array}{l}\text { snowmelt, } \\
\text { rainfall }\end{array}$ & $\begin{array}{l}\text { Göthe (1929) p. } 67, \\
\text { Falkengren (1781), } \\
\text { Riksregistraturet 19/3 } 1639\end{array}$ & $\begin{array}{l}\text { spring flood and raining destroyed fields and } \\
\text { meadows }\end{array}$ \\
\hline 1640 & spring & Sala & Sagån & Norrström & 2 & snowmelt & Edén (1905) p. 267 & $\begin{array}{l}\text { great spring flood stopped silver mining for } 1 \\
\text { month }\end{array}$ \\
\hline 1640 & spring & - & Lake Mälaren & Norrström & 1 & snowmelt & Bring (1924) p. 16 & unusually high water levels on lakes \\
\hline 1640 & bf 28 May & Kopparberget & Faluån & Dalälven & 2 & snowmelt & Edén (1905) p. 269 f & $\begin{array}{l}\text { water dams have barely been saved from the } \\
\text { spring flood which is expected to last another } \\
14 \text { days }\end{array}$ \\
\hline 1640 & 28 June & Karlstad & Klarälven & Göta älv & 3 & snowmelt & Hausen (1880) p. 53 & $\begin{array}{l}\text { mighty high water levels on the lakes; boats could } \\
\text { be rowed across the fields }\end{array}$ \\
\hline 1641 & $\begin{array}{l}\text { summer, } \\
\text { autumn }\end{array}$ & $\begin{array}{l}\text { northern Sweden, } \\
\text { northern Finland }\end{array}$ & - & - & 2 & rainfall & $\begin{array}{l}\text { Wittrock (1948) p. 311, } \\
\text { Lundkvist (1986) }\end{array}$ & $\begin{array}{l}\text { "rain almost every day" during the summer, } \\
\text { damaging the harvests seriously }\end{array}$ \\
\hline 1646 & 10-18 December & Holmens bruk & Motala ström & Motala ström & 2 & rainfall & Helmfrid (1959) p. 67 & $\begin{array}{l}\text { the water in Motala ström began to rise rapidly } \\
\text { around } 10 \text { December, to a level only } 30 \mathrm{~cm} \\
\text { below the furnaces on } 18 \text { December }\end{array}$ \\
\hline 1647 & 19 July & Väsby & - & Norrström & 2 & rainfall & Edén (1905) p. 245 & $\begin{array}{l}\text { mines filled with water after great and continuous } \\
\text { rainfall, causing a stop for mining for } 14 \text { days }\end{array}$ \\
\hline 1648 & - & (Sweden) & - & - & 1 & rainfall & Hausen (1880) p. 135 & very wet year \\
\hline 1649 & spring & Baggetorp & - & Norrström & 2 & snowmelt & Edén (1905) p. 183 & mill dam destroyed by spring flood \\
\hline 1649 & spring & Stockholm & $\begin{array}{l}\text { (Norrström), } \\
\text { Lake } \\
\text { Mälaren }\end{array}$ & Norrström & 3 & rainfall & $\begin{array}{l}\text { Tigerstedt (1888) p. } 45 \text {, } \\
\text { Bring (1924) p. } 16\end{array}$ & $\begin{array}{l}\text { "much wetness and continuous raining" caused } \\
\text { harvest failure and poverty among peasants; Lake } \\
\text { Mälaren high above its banks }\end{array}$ \\
\hline 1649 & summer, autumn & $\begin{array}{l}\text { (Västergötland, } \\
\text { Öland) }\end{array}$ & - & - & 3 & rainfall & Hausen (1880) p. 143 & $\begin{array}{l}\text { "so much water that the ears of the corn could not } \\
\text { be seen" }\end{array}$ \\
\hline 1649 & $\begin{array}{l}7 \text { August } \\
\text { and } \\
\text { following }\end{array}$ & (Östergötland) & - & Motala ström & 3 & rainfall & $\begin{array}{l}\text { Ilmoni (1849) p. 196, } \\
\text { Rydberg (1997), } \\
\text { Alexandersson and } \\
\text { Vedin (2001) }\end{array}$ & $\begin{array}{l}\text { the "Olsmässa flood": severe floods all over the } \\
\text { province, mills, dams, houses, fences, crops and } \\
\text { trees flushed away, cattle and people died, } \\
\text { destroyed harvests for } 3 \text { years afterwards }\end{array}$ \\
\hline 1649 & autumn & (Dalarna Province) & - & Dalälven & 3 & rainfall & Ilmoni (1849) p. 196 & inundations all over the province \\
\hline 1649 & bf 16 October & Stockholm & (Norrström) & Norrström & 2 & rainfall & Sjöberg (1911) p. 16 & $\begin{array}{l}\text { "horrible weather ... it has rained and is still } \\
\text { raining tremendously ... this city [of Stockholm] } \\
\text { must be the potty of the sky" }\end{array}$ \\
\hline 1650 & bf 19 May & - & $\begin{array}{l}\text { Lake } \\
\text { Mälaren }\end{array}$ & Norrström & 2 & snowmelt & $\begin{array}{l}\text { Handl. rör. Skand. hist., } \\
\text { Vol. } 9 \text {, p. } 394, \\
\text { Lilienberg (1891) p. } 35\end{array}$ & $\begin{array}{l}\text { rapidly rising water levels in the lake, damaging } \\
\text { the surroundings }\end{array}$ \\
\hline 1650 & autumn & - & Lake Mälaren & Norrström & 1 & rainfall & Bååth (1916) p. 234 & rising water levels \\
\hline 1656 & bf 21 May & Avesta & Dalälven & Dalälven & 3 & snowmelt & Norberg (1956) p. 32 no. 33 & $\begin{array}{l}\text { "a tremendous spring flood with so much water } \\
\text { that some who live near the river have seen their } \\
\text { beds floating inside their houses" }\end{array}$ \\
\hline 1658 & bf 24 November & Småland Province & - & - & 3 & snowmelt & Holm (1906) p. 346 & $\begin{array}{l}\text { much snow in November melted and became a } \\
\text { flood so great that bridges were destroyed and the } \\
\text { water "stood above the back of the horse" }\end{array}$ \\
\hline 1659 & summer & Stola & Lake Vänern & Göta älv & 2 & rainfall & Sjöberg (1911) 146, 149 pp. & "great wetness" \\
\hline 1660 & spring & $\begin{array}{l}\text { Skedvi, Säter, (Stora) } \\
\text { Tuna }\end{array}$ & Dalälven & Dalälven & 3 & snowmelt & $\begin{array}{l}\text { Riksarkivet, } \\
\text { Bergskollegium, } \\
\text { huvudarkivet, } \\
\text { Bergverksrelationer EII:a } \\
\text { vol. } 2 \text { fol 172, 175, } 177\end{array}$ & $\begin{array}{l}\text { three mines and all water wheels severely } \\
\text { damaged by violent spring flood }\end{array}$ \\
\hline 1661 & spring & $\begin{array}{l}\text { Skedvi, Säter, (Stora) } \\
\text { Tuna }\end{array}$ & Dalälven & Dalälven & 3 & snowmelt & $\begin{array}{l}\text { Riksarkivet, } \\
\text { Bergskollegium, } \\
\text { huvudarkivet, } \\
\text { Bergverksrelationer EII:a } \\
\text { vol. } 2 \text { fol } 175\end{array}$ & $\begin{array}{l}\text { all water wheels severely damaged by violent } \\
\text { spring flood }\end{array}$ \\
\hline 1661 & early spring & Stockholm & $\begin{array}{l}\text { Norrström, } \\
\text { Söderström }\end{array}$ & Norrström & 3 & snowmelt & Bring (1924) p. 16 & $\begin{array}{l}\text { extremely high water due to large quantities of } \\
\text { snow and ice melting, covering the Munkbro } \\
\text { bridge and entering houses; other bridges and the } \\
\text { new lock threatened by the water }\end{array}$ \\
\hline
\end{tabular}


Table A1. Continued.

\begin{tabular}{|c|c|c|c|c|c|c|c|c|}
\hline Year & Date & Location & River & Catchment & Index & Type & Source & Comment \\
\hline 1661 & spring & $\begin{array}{l}\text { Västland and Tolfta } \\
\text { parishes }\end{array}$ & Tämnarån & Tämnarån & 3 & snowmelt & $\begin{array}{l}\text { Landshövdingars } \\
\text { skrivelse t K M:t, } \\
\text { Uppsala län (RA) }\end{array}$ & $\begin{array}{l}\text { great damage from spring flood that covered fields } \\
\text { for a long time }\end{array}$ \\
\hline 1661 & bf 17 August & Stockholm & (Norrström) & Norrström & 2 & rainfall & Sjöberg (1915) p. 270 & "tremendously great wetness" \\
\hline 1662 & autumn & $\begin{array}{l}\text { Södermanland } \\
\text { Province }\end{array}$ & - & Nyköpingsån & 1 & rainfall & Tilander (1968) p. 109 & wet and flooded roads \\
\hline 1663 & bf 10 April & Stockholm & (Norrström) & Norrström & 1 & snowmelt & Sjöberg (1915) p. 369 & great spring flood \\
\hline 1663 & $\begin{array}{l}\text { July, esp. } \\
20-21\end{array}$ & eastern Värmland & & Göta älv & 3 & rainfall & Hausen (1880) p. 270 & $\begin{array}{l}\text { terribly much rain on certain locations; heavy } \\
\text { rainfall on } 20-21 \text { July "as if the sky had opened", } \\
\text { followed by flood which destroyed bridges, dams, } \\
\text { sawmills etc., the meadows were like lakes, the } \\
\text { hay floated away and the water covered the crops, } \\
\text { many pigs drowned }\end{array}$ \\
\hline 1664 & 14-16 September & Värmland Province & & Göta älv & 2 & rainfall & Hausen (1880) 302, 303 pp. & $\begin{array}{l}\text { heavy daily rain and storm with flood and rising } \\
\text { river levels }\end{array}$ \\
\hline 1677 & spring & Falun & Faluån & Dalälven & 1 & snowmelt & Hildebrand (1946) p. 331 & material damages \\
\hline 1677 & spring & Stöpsjöhyttan & Stöpsjön & Göta älv & 2 & snowmelt & Danielson (1974) 19 pp. & $\begin{array}{l}\text { severe spring flood, damages at the furnace } \\
\text { facilities }\end{array}$ \\
\hline 1677 & spring & Njurunda & Ljungan & Ljungan & 3 & snowmelt & Hülphers (1780) p. 30 & great flood, causing much damage \\
\hline 1677 & 5 June & - & Torne älv & Torne älv & 3 & snowmelt & $\begin{array}{l}\text { Hellant (1747), Keksi } \\
\text { (1936-1945), Olofsson } \\
\text { and Liedgren (1974) } \\
\text { p. 93, Fahlgren (1956) } \\
\text { p. 48 }\end{array}$ & $\begin{array}{l}\text { great flood, causing much damage on buildings } \\
\text { and killing cattle }\end{array}$ \\
\hline 1680 & spring & Hännickehammaren & Stampbäc-ken & Göta älv & 2 & snowmelt & Furuskog (1924) p. 133 & violent spring flood destroyed the furnace \\
\hline 1684 & bf 27 April & Vaksala & Lillån & Norrström & 2 & snowmelt & $\begin{array}{l}\text { letter from the peasants } \\
\text { in Vaksala } 17 \text { April } \\
\text { 1684, RA, } \\
\text { Landshövdingens i } \\
\text { Uppsala län skrivelser till } \\
\text { K. M.:t }\end{array}$ & bridges destroyed by spring flood \\
\hline 1684 & spring & Söderköping & Storån & Storån & 3 & snowmelt & Broocman (1760) p. 149 & $\begin{array}{l}\text { severe spring flood; the water rose to } 0.5 \mathrm{~m} \text { above the } \\
\text { benches in the St. Laurentii church and } 0.5 \mathrm{~m} \\
\text { above the floor, watermark on wall in church }\end{array}$ \\
\hline 1686 & spring & $\begin{array}{l}\text { Nordhallen, } \\
\text { (Jämtland) }\end{array}$ & Indalsälven & Indalsälven & 1 & snowmelt & $\begin{array}{l}\text { Hildebrand (1918) p. } 115 \text {, } \\
\text { Lundström (1912) p. } 249\end{array}$ & great spring flood \\
\hline 1686 & bf 15 June & Lundby & - & Tyresån & 2 & rainfall & Wijkmark (1995) p. 436 & continuous rain and storms for several days \\
\hline 1691 & bf 1 March & Vaxholm & - & Åkersström & 2 & snowmelt & $\begin{array}{l}\text { letter from the governor } \\
\text { of Uppsala Province } \\
19 \text { February 1691, RA, } \\
\text { Landshövdingens i } \\
\text { Uppsala län skrivelser till } \\
\text { K. M.:t }\end{array}$ & barrier damaged by spring flood \\
\hline 1697 & bf 1 May & Nykvarn & $\begin{array}{l}\text { Brants- } \\
\text { hammarsån }\end{array}$ & Norrström & 2 & snowmelt & $\begin{array}{l}\text { letter from the governor } \\
\text { of Uppsala Province } \\
4 \text { April } 1697, \text { RA, } \\
\text { Landshövdingens i } \\
\text { Uppsala län skrivelser till } \\
\text { K. M.:t }\end{array}$ & damages on ferry and mill \\
\hline 1697 & spring & Rytterne & Åbäcken & Norrström & 1 & snowmelt & Hülphers (1793) p. 319 & great spring flood \\
\hline 1703 & 6-7 July & Ydre & - & Motala ström & 2 & rainfall & Rääf (1875) p. 350 & $\begin{array}{l}\text { "great rainfall ... hardly any spring flood could be } \\
\text { greater than the flood that followed" }\end{array}$ \\
\hline 1705 & 27 May & Gotland & - & - & 2 & rainfall & Kellgren (1931) p. $18 \mathrm{f}$ & $\begin{array}{l}\text { "snowing all day followed by much rain and great } \\
\text { waterflood", not so much damage on crops as on } \\
\text { hay }\end{array}$ \\
\hline 1707 & bf 2 January & Ljustorp, Medelpad & Ljustorpsån & Indalsälven & 3 & $\begin{array}{l}\text { rainfall, } \\
\text { snowmelt }\end{array}$ & Hülphers (1771) p. 112 & $\begin{array}{l}\text { enduring rain and great waterflood destroyed } \\
\text { bridges and water dams }\end{array}$ \\
\hline 1707 & summer & Rytterne & Åbäcken & Norrström & 2 & rainfall & Hülphers (1793) p. 321 & "wet summer", hay and rye crops damaged \\
\hline 1707 & summer & - & Lake Vänern & Göta älv & 1 & rainfall & Wallén (1910) p. 13 & much raining \\
\hline 1707 & $\begin{array}{l}\text { summer, } \\
\text { autumn }\end{array}$ & Gotland & - & - & 2 & rainfall & Kellgren (1931) p. 20 & $\begin{array}{l}\text { violent and enduring rain, wetness continued until } \\
\text { New Year }\end{array}$ \\
\hline 1709 & 13 March & Ekby & Tidan & Göta älv & 3 & snowmelt & Bergstrand (1934) p. 188 & $\begin{array}{l}\text { severe winter followed by spring flood which } \\
\text { almost reached the parish church }(2 \mathrm{~km} \text { from the } \\
\text { river) }\end{array}$ \\
\hline
\end{tabular}


Table A1. Continued.

\begin{tabular}{|c|c|c|c|c|c|c|c|c|}
\hline Year & Date & Location & River & Catchment & Index & Type & Source & Comment \\
\hline 1709 & spring & Norrköping & $\begin{array}{l}\text { Norrköpings } \\
\text { ström, Lake } \\
\text { Roxen }\end{array}$ & Motala ström & 3 & snowmelt & $\begin{array}{l}\text { Ringborg (1920) p. } 92 \\
\text { Stille (1903) p. } 146 \mathrm{f}\end{array}$ & great spring flood causing poverty among peasants \\
\hline 1709 & spring & Uppsala & Fyrisån & Norrström & 3 & snowmelt & Annerstedt (1912) p. 128 & $\begin{array}{l}\text { water dams completely ruined by great } \\
\text { spring flood }\end{array}$ \\
\hline 1709 & spring & Gotland & - & - & 3 & snowmelt & Kellgren (1931) p. 25 & $\begin{array}{l}\text { great spring flood causing much damage on } \\
\text { sawmills and other mills }\end{array}$ \\
\hline 1710 & May & Hälsingland Province & - & - & 1 & snowmelt & $\begin{array}{l}\text { Hægermarck and } \\
\text { Grape (1911-1949) p. } 340\end{array}$ & quite great but not enduring spring flood \\
\hline 1711 & $\begin{array}{l}12,13 \\
16 \text { July }\end{array}$ & Hälsingland Province & - & - & 1 & rainfall & $\begin{array}{l}\text { Hægermarck and } \\
\text { Grape (1911-1949) p. } 348\end{array}$ & $\begin{array}{l}\text { great flood caused by much rain; hay ruined, mill } \\
\text { channels full, as in spring }\end{array}$ \\
\hline 1712 & $\begin{array}{l}21 \text { October- } \\
11 \text { November }\end{array}$ & Hälsingland Province & - & - & 2 & rainfall & $\begin{array}{l}\text { Hægermarck and } \\
\text { Grape (1911-1949) p. } 353\end{array}$ & $\begin{array}{l}\text { "the month of October all wet ... continuous } \\
\text { raining, wind and fog so that, contrary to the } \\
\text { usual, creeks and rivers swelled even more than in } \\
\text { the spring ... caused much damage" }\end{array}$ \\
\hline 1714 & 15-16 September & Hälsingland Province & - & - & 3 & rainfall & $\begin{array}{l}\text { Hægermarck and } \\
\text { Grape (1911-1949) p. } 360\end{array}$ & $\begin{array}{l}\text { in two days "fell so terribly much rain that all } \\
\text { creeks, lakes, meadows were covered. No } \\
\text { spring flood could be greater", great damages; } \\
\text { bridges, millhouses, barns, boats destroyed and } \\
\text { great slides of chunks of earth }\end{array}$ \\
\hline 1717 & early May & Hälsingland Province & - & - & 1 & snowmelt & $\begin{array}{l}\text { Hægermarck and } \\
\text { Grape (1911-1949) p. } 366\end{array}$ & unusually great spring flood \\
\hline 1720 & 24-30 October & Hälsingland Province & - & - & 1 & rainfall & $\begin{array}{l}\text { Hægermarck and } \\
\text { Grape (1911-1949) p. } 380\end{array}$ & $\begin{array}{l}\text { much rain on } 24 \text { and even more on } 27 \text {, and again } \\
\text { on } 28-30 \text { October; rising sea level }\end{array}$ \\
\hline 1721 & spring & $\begin{array}{l}\text { Västerbotten } \\
\text { Province }\end{array}$ & - & - & 2 & snowmelt & Lundmark (1990) p. 155 & great spring flood ruined fishing of the season \\
\hline 1724 & 20 April & Örebro & Svartån & Norrström & 2 & snowmelt & Linder (1916) p. 25 & $\begin{array}{l}\text { the excessive water submerged poles in the } \\
\text { harbour }\end{array}$ \\
\hline 1724 & spring & Långared & Säveån & Göta älv & 2 & snowmelt & Bergstrand (1954) p. 24 & great spring flood causing inundations \\
\hline 1725 & summer & $\begin{array}{l}\text { Västergötland } \\
\text { Province }\end{array}$ & - & Göta älv & 2 & rainfall & Bergstrand (1934) p. 154 & extremely rainy summer \\
\hline 1728 & spring & Mora southwards & Dalälven & Dalälven & 3 & snowmelt & Norberg (1956) p. 325 & $\begin{array}{l}\text { great spring flood damaged all bridges between } \\
\text { Mora and the provincial border }\end{array}$ \\
\hline 1728 & spring & Järbo & Jädraån & Dalälven & 2 & snowmelt & Norberg (1958-1959) p. 243 & iron furnace destroyed by spring flood \\
\hline 1728 & spring & Jämtland Province & - & Indalsälven & 1 & snowmelt & Hasselberg (1930) & high waters due to spring flood \\
\hline 1728 & spring & Njurunda & Ljungan & Ljungan & 1 & snowmelt & Hülphers (1780) p. 30 & great spring flood \\
\hline 1729 & spring & Jämtland Province & - & Indalsälven & 1 & snowmelt & Hasselberg (1930) & high waters due to spring flood \\
\hline 1730 & spring & Säter & Dalälven & Dalälven & 2 & snowmelt & Ericsson (1970) p. 73 & the mill severely damaged by spring flood \\
\hline 1730 & spring & Holmen & Hällestadsån & Motala ström & 2 & snowmelt & $\begin{array}{l}\text { Helmfrid (1954) p. } 109 \\
\text { Ericsson (1970) p. } 73\end{array}$ & water dam at Säter damaged by spring flood \\
\hline 1733 & August & Hälsingland Province & - & - & 3 & rainfall & $\begin{array}{l}\text { Hægermarck and } \\
\text { Grape (1911-1949) p. } 380\end{array}$ & $\begin{array}{l}\text { continuous rain day and night throughout the } \\
\text { month of August; swamps and meadows filled } \\
\text { with water and streams and creeks greater than in } \\
\text { spring floods so that one could travel over them in } \\
\text { boats; hay and corn destroyed. High sea level }\end{array}$ \\
\hline 1740 & summer & - & Lake Vänern & Göta älv & 1 & rainfall & Wallén (1910) p. 13 & "wet year" \\
\hline 1740 & summer & $\begin{array}{l}\text { southern and } \\
\text { southeastern Sweden }\end{array}$ & - & - & 1 & rainfall & $\begin{array}{l}\text { Utterström (1957), Vol. } 2 \\
\text { p. } 429\end{array}$ & "much wetness" \\
\hline 1743 & spring & Jämtland Province & - & Indalsälven & 1 & snowmelt & Hasselberg (1930) & high waters due to spring flood \\
\hline 1743 & 28 May & Avesta & Dalälven & Dalälven & 2 & snowmelt & Norberg (1956) p. 683 & $\begin{array}{l}\text { river bridge broken down by great spring flood } \\
\text { and storm }\end{array}$ \\
\hline 1743 & May & Avesta & Dalälven & Norrström & 2 & snowmelt & $\begin{array}{l}\text { Norberg (1956) Vol. } 2 \\
\text { p. } 683\end{array}$ & river bridge destroyed by spring flood \\
\hline 1745 & spring & Uppland & - & Norrström & 1 & snowmelt & Utterström (1957) p. 430 & great spring flood \\
\hline 1745 & spring & $\begin{array}{l}\text { (Västergötland } \\
\text { Province) }\end{array}$ & - & Göta älv & 1 & snowmelt & $\begin{array}{l}\text { Utterström (1957) Vol. } 2 \\
\text { p. } 430, \text { Ny journal } \\
(1776-1813) \text { p. } 33\end{array}$ & great spring flood \\
\hline 1745 & 15 July & Stöde & Indalsälven & Indalsälven & 1 & $\begin{array}{l}\text { torrential } \\
\text { rain }\end{array}$ & Nordenström (1894) p. 43 & $\begin{array}{l}\text { "great rain on the 14th, as if the sky had opened } \\
\text { with a great rainflood" }\end{array}$ \\
\hline 1753 & 13 August & Stöde & Indalsälven & Indalsälven & 1 & rainfall & Nordenström (1894) p. 44 & great flood caused by rain \\
\hline 1754 & August & Uppsala & Fyrisån & Norrström & 2 & rainfall & Ferner (1756) $287 \mathrm{pp}$. & wet; much hay and corn destroyed by wetness \\
\hline 1755 & spring & Stöde & Indalsälven & Indalsälven & 1 & snowmelt & Nordenström (1894) p. 44 & great spring flood \\
\hline
\end{tabular}


Table A1. Continued.

\begin{tabular}{|c|c|c|c|c|c|c|c|c|}
\hline Year & Date & Location & River & Catchment & Index & Type & Source & Comment \\
\hline 1756 & 11 June & Stöde & Indalsälven & Indalsälven & 2 & snowmelt & Nordenström (1894) p. 44 & great spring flood, water rising above the fields \\
\hline 1759 & ca. 15 June & Stöde & Indalsälven & Indalsälven & 2 & rainfall & Nordenström (1894) p. 45 & rain flood greater than this year's spring flood \\
\hline 1763 & 20 July & Stöde & Indalsälven & Indalsälven & 2 & rainfall & Nordenström (1894) p. 45 & rain flood destroying hay harvest \\
\hline 1777 & summer & $\begin{array}{l}\text { Västergötland } \\
\text { Province }\end{array}$ & - & Göta älv & 2 & rainfall & Bergstrand (1934) p. 154 & $\begin{array}{l}\text { continuous rains, few persons could remember } \\
\text { anything similar }\end{array}$ \\
\hline 1778 & $31 \mathrm{March}$ & Söderköping & Storån & Storån & 3 & rainfall & Ny journal (1776-1813) p. 115 & $\begin{array}{l}\text { great rainfall, flooding the river which covered } \\
\text { seven bridges, waters entered church and streets }\end{array}$ \\
\hline 1780 & March & $\begin{array}{l}\text { Västmanland } \\
\text { Province }\end{array}$ & $\begin{array}{l}\text { Lake } \\
\text { Mälaren }\end{array}$ & Norrström & 2 & snowmelt & Utterström (1957) p. 435 & $\begin{array}{l}\text { unprecedented great spring flood following a } \\
\text { severe, snow-rich and long winter }\end{array}$ \\
\hline 1780 & March & Stockholm & (Norrström) & Norrström & 3 & snowmelt & Ny journal (1776-1813)l p. 231 & $\begin{array}{l}\text { great spring flood in creeks and streams, } \\
\text { unprecedented water levels of the Lake Mälaren, } \\
\text { rising up to } 4 \mathrm{ft} \text {. higher than usual }\end{array}$ \\
\hline 1780 & May & Uppsala & Fyrisån & Norrström & 3 & snowmelt & Ny journal (1776-1813) p. 163 & $\begin{array}{l}\text { great spring flood following an "unnaturally" } \\
\text { snow-rich winter; the waters rose to the } \\
\text { windows of the houses and into the gardens which } \\
\text { were destroyed }\end{array}$ \\
\hline 1780 & early May & Nordmarks hytta & $\begin{array}{l}\text { Nordmarks- } \\
\text { älven }\end{array}$ & Göta älv & 3 & snowmelt & Danielson (1974) p. $38 \mathrm{f}$ & $\begin{array}{l}\text { the iron furnace at Nordmark destroyed by sudden } \\
\text { and great spring flood }\end{array}$ \\
\hline 1780 & spring & Jämtland Province & - & Indalsälven & 1 & snowmelt & Hasselberg (1930) & high waters due to spring flood \\
\hline 1782 & autumn & Närke Province & - & Norrström & 2 & rainfall & Ny journal (1776-1813) p. 224 & 1 entire month of continuous raining \\
\hline 1785 & autumn & Uddevalla & Bäveån & Strömsån & 3 & rainfall & Ny journal (1776-1813) p. 33 & $\begin{array}{l}\text { extreme autumn rains rose the waters of the river } \\
\text { to the highest in } 40 \text { years; four bridges, six } \\
\text { grainmills and other facilities destroyed }\end{array}$ \\
\hline 1788 & March & Norrköping & $\begin{array}{l}\text { Norrköpings } \\
\text { ström }\end{array}$ & Motala ström & 1 & snowmelt & Ny journal (1776-1813) p. 88 & great spring flood with some damage \\
\hline
\end{tabular}




\section{Appendix B}

Table B1. Documentary data on harvest failures related to Sweden, 1200-1600, without specified cause.

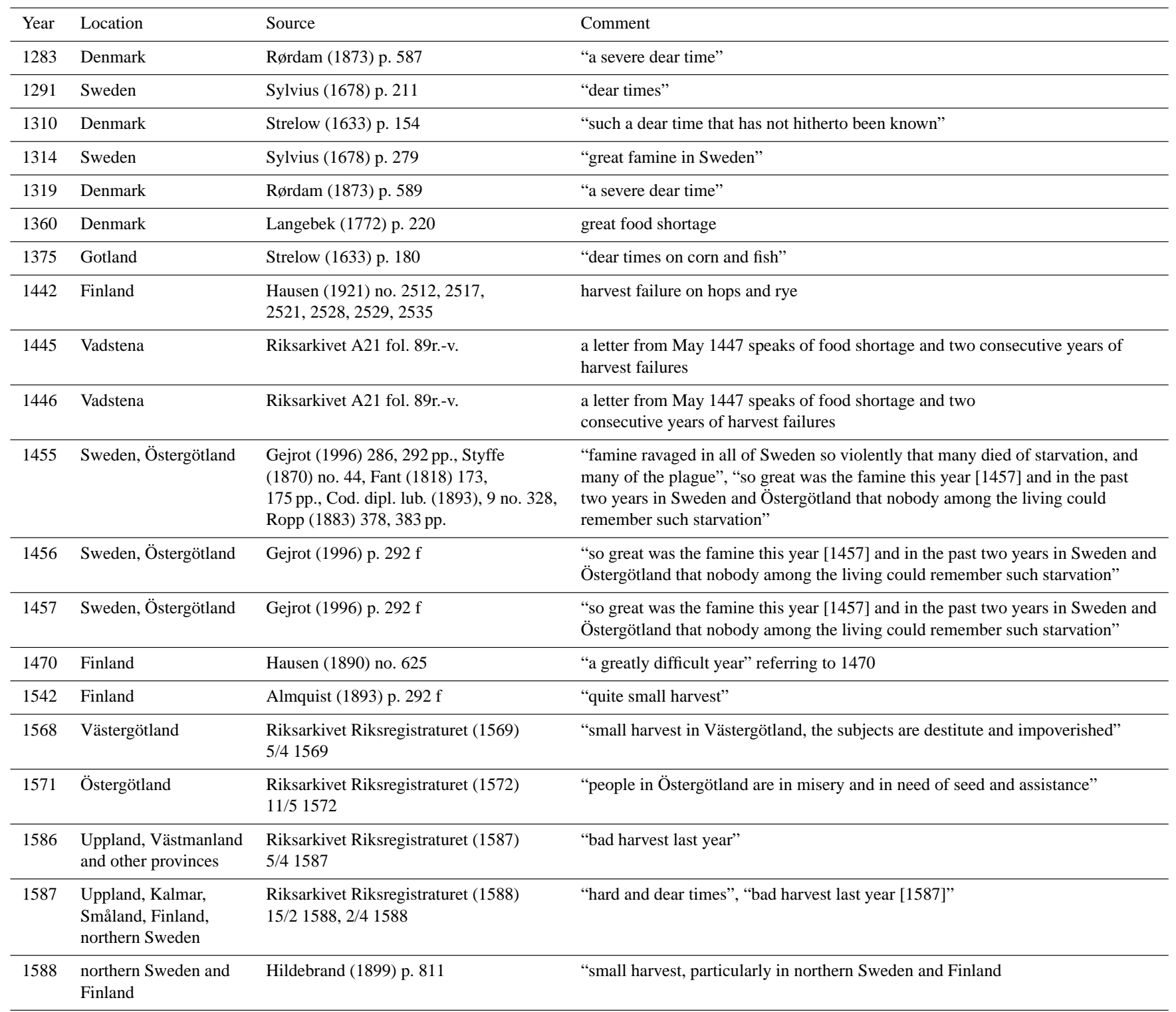


Acknowledgements. I wish to thank the referees for useful comments.

Edited by: A. Kiss

\section{References}

Ahlbäck, A. and Albertsson, R.: Flottning och flottleder i södra Sverige, Arnold Ahlbäck, Huskvarna, 2006.

Ahlqvist, A.: Ölands historia och beskrifning, Del. 2, Calmar, 1825.

Ahnlund, N. (Ed.): Peder Galts Depescher 1622-1624, Historiska handlingar 26:1, Stockholm, 1920.

Ahnlund, N. (Ed.): Rikskansleren Axel Oxenstiernas skrifter och brefvexling, Avd. 2, Bd 12, Del. 1, Brev från andlige och lärde, Kungl. Vitterhets historie och antikvitets akademien, Stockholm, 1930

Alexandersson, H. and Vedin, H.: Översvämningar i Sverige: Olsmässofloden i Östergötland 1649, Väder och vatten, July 2001.

Almquist, J. A. (Ed.): Konung Gustaf den förstes registratur, Vols. 4, 6, 7, 15, 20, 21, 27, Norstedt, Stockholm, 1868, 1875, 1877, 1893, 1902, 1903, 1913.

Annerstedt, C. (Ed.): Upsala universitets historia, Bihang III, Uppsala, 1912.

Bååth, L. M.: Helgeandsholmen och Norrström från älsta tid till våra dagar, Del. 1, Tiden till 1718, Almqvist \& Wiksell, Uppsala, 1916.

Barker, P. A., Wilby, R. L., and Borrows, J.: A 200-year precipitation index for the central English Lake District, Hydrolog. Sci. J., 49, 769-785, 2004.

Bell, W. and Ogilvie, A. E.: Weather compilations as a source of data for the reconstruction of European climate during the medieval period, Climatic Change, 1, 331-348, 1978.

Benestad, R. E. and Haugen, J. E.: On complex extremes: flood hazards and combined high spring-time precipitation and temperature in Norway, Climatic Change, 85, 381-406, 2007.

Benito, G., Díez-Herrero, A., Fernández de Villalta, M.: Magnitude and frequency of flooding in the Tagus basin (central Spain) over the last millennium, Climatic Change, 58, 171-192, 2003.

Bergstrand, C.-M.: Kulturbilder från 1700-talets Västergötland, Vol. 2, Göteborg, 1934.

Bergstrand, C.-M.: Långareds krönika, Vol. 1, Göteborg, 1954.

Bouwer, L. M., Vermaat, J. E., and Aerts, J. C. H.: Winter atmospheric circulation and river discharge in northwest Europe, Geophys. Res. Lett., 33, L06403, doi:10.1029/2005GL025548, 2006.

Brahe, A.: Abraham Brahes tidebok, Norstedt, Stockholm, 1920.

Brázdil, R., Glaser, R., Pfister, C., Dobrovolný, P., Antoine, J.-M., Barriendos, M., Camuffo, D., Deutsch, M., Enzi, S., Guidoboni, E., Kotyza, O., and Rodrigo, F. S.: Flood events of selected European rivers in the $16^{\text {th }}$ century, Climatic Change $43,239-285$, 1999.

Brázdil, R., Pfister, C., Wanner, H., Von Storch, H., Luterbacher, J.: Historical climatology in Europe: the state of the art, Climatic Change, 70, 363-430, 2005.

Brázdil, R., Dobrovolný, P., Luterbacher, J., Moberg, A., Pfister, C., Wheeler, D., and Zorita, E.: European climate of the past 500 years: new challenges for historical climatology, Climatic Change, 101, 7-40, 2010.
Bring, S. E.: Trollhätte kanals historia till 1844, Kungl. Vattenfallsstyrelsen, Stockholm, 1911.

Bring, S. E.: Södertälje kanals historia till 1819, Uppsala, 1924.

Broocman, C. F.: Beskrifning öfwer the i Öster-Göthland befintelige städer, slott, sokne-kyrkor, soknar, säterier, öfwerofficersboställen, jernbruk och prestegårdar, med mera, Norrköping, 1760.

Burt, T. P. and Howden, N. J. K.: North Atlantic Oscillation amplifies orographic precipitation and river flow in upland Britain, Water Resour. Res., 49, 3504-3515, 2013.

Casanueva, A., Rodríguez-Puebla, C., Frías, M. D., and GonzálezReviriego, N.: Variability of extreme precipitation over Europe and its relationships with teleconnection patterns, Hydrol. Earth Syst. Sci., 18, 709-725, doi:10.5194/hess-18-709-2014, 2014.

Casty, C., Wanner, H., Luterbaqcher, J., Esper., J., and Böhm, R., Temperature and precipitation variability in the European Alps since 1500, Int. J. Climatol., 25, 1855-1880, 2005.

Cod. dipl. lub. - Codex diplomaticus lubecensis: Abt. 1, Urkundenbuch der Stadt Lübeck, T. 9, Lübeck, 1451-1460, 1893.

Cook, E. R., D'Arrigo, R. D., and Briffa, K. R.: A reconstruction of the North Atlantic Oscillation index using tree-ring chronologies from North America and Europe, Holocene, 8, 9-17, 1998.

Cook, E. R., D’Arrigo, R., and Mann, M. M.: A well-verified, multiproxy reconstruction of the winter North Atlantic Oscillation index since A. D. 1400, J. Climate, 15, 1754-1764, 2002.

Collmar, M.: Olycksåren 1596-1603, Sörmlandsbygden, 29, 83-87, 1960.

Cronholm, A. P.: Sveriges historia under Gustaf II Adolphs regering, Del. 4, Stockholm, 1864.

Crull, F. (Ed.): Die Chronik Heinrichs von Balsee, Stadtschreibers zu Wismar, Jahrbücher des Vereins für Mecklenburgische Geschichte und Altertumskunde, 1878.

Danielson, T.: Stöpsjöhyttan, Färnebo socken, Värmlands län 16011974, Bronells, Hedemora, 1974.

De Kraker, A. M. J., Flood events in the southwestern Nethelands and coastal Belgium, 1400-1953, Hydrolog. Sci. J., 51, 913-929, 2006.

Edén, N. (Ed.): Rikskansleren Axel Oxenstiernas skrifter och brefvexling, Afd 2, Bd. 11: Carl Bonde och Louis De Geer $\mathrm{m}$ fl bref angående bergverk, handel och finanser, Kungl. Vitterhets historie och antikvitets akademien, Stockholm, 1905.

Edman, B.: ... Äro fem valar vid Ronnö: Ur Ålems äldsta kyrkobok, Kalmar län, 70-86, 1985.

Ekman, E.: Undersökning om årsväxtens förhållande, och i synnerhet missväxt-åren i Sverige, från år 1523 til år 1781, Stockholm, 1783.

Ekström, G.: Västerås stifts herdaminne 1. Medeltiden och reformationstiden, del 2, Återstående församlingar, Västerås, 1949.

Elleder, L., Herget, J., Roggenkamp, T., and Niessen, A.: Historic floods in the city of Prague: a reconstruction of peak discharges for 1481-1825 based on documentary sources, Hydrol. Res., 44, 202-214, 2013.

Elvius, P.: Dag-bok, Stockholm, 1751-1752.

Ericsson, B.: Bergsstaden Falun 1720-1769, Uppsala, 1970.

Fahlgren, K.: Skellefte sockens historia, Del. 1, Bd. 2, Almqvist \& Wiksell, Uppsala, 1956.

Falkengren, C.: Några anmärkningar angående årstiderna och väderleken, ifrån år 1617 till år 1639 fundne uti Kongl. Riks- 
Archivum, Kungl. Svenska vetenskapsakademiens handlingar, Juli, Augusti, September 1781, Stockholm, 1781.

Fant, E. M. (Ed.): Scriptores rerum suecicarum medii ævi, Tomo 1: Ex schedis præcipue Nordinianis collectos, dispositos ac emendatos, Upsaliæ, 1818.

Ferner, B.: Utdrag af meteorologiska observationer, hållne i Upsala år 1754, Kungl. Svenska vetenskapsakademiens handlingar, Vol. 17, Stockholm, 1756.

Forssell, H.: Anteckningar om Sveriges jordbruksnäring i sextonde seklet, Samson \& Wallin, Stockholm, 1884.

Furuskog, J.: De värmländska järnbruken: Kulturgeografiska studier över den värmländska järnhanteringen under dess olika utvecklingsskeden, Filipstad, 1924.

Gejrot, C. (Ed.): Vadstenadiariet, Samf. för utgivande av handskrifter rörande Skandinaviens historia, Stockholm, 1996.

Glaser, R.: Klimageschichte Mitteleuropas: 1200 Jahre Wetter, Klima, Katastrophen, Primus, Darmstadt, 2008.

Glaser, R. and Stangl, H.: Climate and floods in central Europe since AD 1000: data, methods, results and consequences, Surv. Geophys., 25, 485-510, 2004.

Glaser, R., Riemann, D., Schönbein, J., Barriendos, M., Brázdil, R., Bertolin, C., Camuffo, D., Deutsch, M., Dobrovolný, P., van Engelen, A., Enzi, S., Halíčková, M., Koenig, S. J., Kotyza, O., Limanówka, D., Macková, J., Sghedoni, M., Martin, B., Himmelsbach, I.: The variability of European floods since AD 1500, Climatic Change, 101, 235-256, 2010.

Glueck, M. F. and Stockton, C. W., Reconstruction of the North Atlantic Oscillation, 1429-1983, Int. J. Climatol., 21, 1453-1465, 2001

Göthe, G.: Om Umeå lappmarks svenska kolonisation: Från mitten av 1500-talet till omkr 1750, Almqvist \& Wiksell, Uppsala, 1929.

Granlund, V. (Ed.): Konung Johan III:s bygnads - och befästningsföretag: Bref ur Riks-registraturet 1568-1592, Del. 2, Historiskt bibliotek, Stockholm, 1876.

Hægermarck, K. A. and Grape, H. (Eds.): Olof Joh. Bromans Glysisvallur och öfriga skrifter rörande Helsingland, Del. 1, Uppsala, 1911-1949.

Hall, J., Arheimer, B., Borga, M., Brázdil, R., Claps, P., Kiss, A., Kjeldsen, T. R., Kriaučiūnienè, J., Kundzewicz, Z. W., Lang, M., Llasat, M. C., Macdonald, N., McIntyre, N., Mediero, L., Merz, B., Merz, R., Molnar, P., Montanari, A., Neuhold, C., Parajka, J., Perdigão, R. A. P., Plavcová, L., Rogger, M., Salinas, J. L., Sauquet, E., Schär, C., Szolgay, J., Viglione, A., and Blöschl, G.: Understanding flood regime changes in Europe: a state-of-the-art assessment, Hydrol. Earth Syst. Sci., 18, 27352772, doi:10.5194/hess-18-2735-2014, 2014.

Hallendorff, C.: Ur en svensk kyrkobok från slutet av 1500-talet, Kyrkohistorisk årsskrift, 1902.

Handlingar rörande Skandinaviens historia, Del. 9, Samf. för utgivande av handskrifter rörande Skandinaviens historia, Stockholm, 1821.

Handlingar rörande Skandinaviens historia, Del. 19, Samf. för utgivande av handskrifter rörande Skandinaviens historia, Stockholm, 1834.

Hasselberg, G. (Ed.): Fale Burmans anteckningar om Jämtland i urval, Skrifter utgivna av Jämtlands läns fornskriftsällskap, Östersund, 1930.
Hausen, R. (Ed.): Diarium Gyllenianum eller Petrus Magni Gyllenii dagbok 1622-1667, Förra häftet, Finska Statsarkivet, Helsingfors, 1880 .

Hausen, R. (Ed.): Registrum ecclesiæ Aboensis eller Åbo domkyrkas svartbok, Finska Statsarkivet, Helsingfors, 1890.

Hausen, R. (Ed.): Finlands medeltidsurkunder, Del. 3, 1431-1450, Finska Statsarkivet, Helsingfors, 1921.

Hellant, A.: Almanach för skott-åhret, efter Christi födelse, 1748, Til Torne horizont ..., Stockholm, 1747.

Helmfrid, B.: Holmenöden under fyra sekler: Studier i Holmens bruks historia, Acta Holmenensia, Norrköping, 1954.

Helmfrid, B.: "De på stenhuset": Studier från Holmens bruks första storhetstid tillägnade Christian von Sydow 5/6 1959, Acta Holmenensia, Åby, 1959.

Hildebrand, E. (Ed.): Svenska riksdagsakter jämte andra handlingar som höra till statsförfattningens historia, (Ser. 1), Under tidehvarfvet 1521-1718, [Afd. 1], [1521-1611], Del. 2, 2, Stockholm, 1561-1592, 1899

Hildebrand, K.-G.: Falu stads historia 1641-1687, Falun, 1946.

Hildebrand, S. (Ed.): Karl XI:s almanacksanteckningar, Norstedt, Stockholm, 1918.

Holder-Egger, O. (Ed.): Monumenta Germaniæ historica, Scriptores rerum germanicarum, Vol. 25, Balduini Ninovensis chronicon, Hannover, 1880.

Holm, R.: Joannes Elai Terserus: Hans insats i samtidens kyrkliga, vetenskapliga och politiska lif, Del. 1, Terseri lif och verksamhet intill år 1659, Lund, 1906.

Hülphers, A. A.: Samlingar til en beskrifning öfwer Norrland. Saml. 1, Om Medelpad, Westerås, 1771.

Hülphers, A. A.: Utdrag af Kyrkoherden i Ryttern Nic. Nic. Kroks anmärkningar i Almanackor, Kungl Svenska vetenskaps academiens nya handlingar, Tom. XIV för år 1793, Stockholm, 1793.

Hülphers, A. A.: Samlingar til en beskrifning öfwer Norrland. Saml. 4, Om Ångermanland, Westerås, 1780.

Hurrell, J. W. and Van Loon, H.: Decadal variation in climate associated with the North Atlantic Oscillation, Climatic Change, 36, 301-326, 1997.

Ilmoni, I.: Bidrag till nordens sjukdoms-historia, Del. 2, Bidrag till historien om nordens sjukdomar från sextonde seklets början till slutet af det adertondes första decennium, Helsingfors, 1849.

Jacobeit, J., Glaser, R., Luterbacher, J., and Wanner, H.: Links between flood events in central Europe since AD 1500 and largescale atmospheric circulation modes, Geophys. Res. Lett., 30, 1172, doi:10.1029/2002GL016433, 2003.

Jämtländska räkenskaper 1564-1571, Vol. 2, Räkenskaper 15681571, Skrifter utgivna av Jämtlands läns fornskriftsällskap, Östersund, 1564-1571.

Jansson, S.-B. (Ed.): Erikskrönikan, Prisma, Stockholm, 2003.

Jørgensen, E.: Middelalderlig historisk litteratur paa modersmaalet, Samfund til Udgivelse af gammel nordisk Litteratur, København, 1930.

Keksi, A.: Keksin laulu (Kexis sång) om isgången i Torne älv 1677 av Antero Keksi, som levde i Övertorneå socken på 1600-talet, Tornedalen, 53-61, 1936-1945.

Kellgren, G.: Om skördeförhållandena på Gotland under Karl XII:s regering, Karolinska förbundets årsbok, 1931.

Kiss, A.: Floods and weather in 1342 and 1343 in the Carpathian basin, J. Environ. Geogr., 2, 37-47, 2009. 
Langebek, J. (Ed.): Scriptores rerum Danicarum medii ævi, Vol. 1, Hafniæ, 1772.

Langebek, J. and Suhm, P. F. (Eds.): Scriptores rerum Danicarum medii ævi, Vol. 6, Hafniæ, 1786.

Larsson, L.-O.: Gustav Vasa - landsfader eller tyrann?, Prisma, Stockholm, 2002.

Lavers, D. A., Villarini, G., Allan, R. P., Wood, E. F., and Wade, A. J.: The detection of atmospheric rivers in atmospheric reanalyses and their links to British winter floods and the large-scale climatic circulation, J. Geophys. Res.-Atmos., 117, D20106, doi:10.1029/2012JD018027, 2012.

Leijonhufvud, L., Wilson, R., Moberg, A., Söderberg, J., Retsö, D., and Söderlind, U.: Five centuries of Stockholm winter/spring temperatures reconstructed from documentary evidence and instrumental observations, Climatic Change, 101, 109-141, 2010.

Le Roy Ladurie, E.: Times of Feast, Times of Famine: A History of Climate since the Year 1000, Garden City, NJ, 1971.

Lewenhaupt, A. (Ed.): Calendaria Caroli IX, Stockholm, 1903.

Lilienberg, V. E.: Om strömmarna i Stockholm: Undersökningar och beräkningar, Looström \& K., Stockholm, 1891.

Lindblom, J. A. (Ed.): Lönberga Kyrko-Bok ifrån och med År 1596 til och med år 1692, Linköpings bibliotheks handlingar, Vol. 1, Linköping, 1793.

Linder, H.: Örebro skeppare ämbetes årskrönika åren 1689-1872, Meddelanden från Örebro läns museum, 1-6, 1916.

Linderholm, H. W., Solberg, В. Ø., and Lindholm, M.: Tree-ring records from central Fennoscandia: the relationship between tree growth and climate along a west-east transect, Holocene, 13, 887-895, 2003.

Lindholm, M., Ogurtsov, M., Aalto, T., Jalkanen, R., and Salminen, H.: A summer temperture proxy from height increment of Scots pine since 1561 at the northern timberline in Fennoscandia, Holocene, 19, 1131-1138, 2009.

Lindström, G. and Alexandersson, H.: Recent mild and wet years in relation to long observation records and climate change in Sweden, Ambio, 33, 183-186, 2004.

Llasat, M.-C., Barriendos, M., Barrera, A., Rigo, T.: Floods in Catalonia (NE Spain) since the $14^{\text {th }}$ century, Climatological and meteorological aspects from historical documentary sources and old instrumental records, J. Hydrol., 313, 32-47, 2005.

Lundkvist, T. (Ed.): Boken om Säbrå: Kommunens och socknarnas historia: Säbrå, Häggdånger, Stigsjö, Viksjö, Hemsö, Angermannia, Härnösand, 1986.

Lundmark, L.: Hushållning inom snäva ramar: lokal försörjning och centrala ingrepp i nedre Lule älvdal 1550-1750, Älvdal i norr: människor och resurser i Luledalen 1300-1800, edited by: Åkerman, L. and Lundholm, K., Umeå, 1990.

Lundström, H. (Ed.): Erik Dahlberghs dagbok (1625-1699), Almqvist \& Wiksell, Upsala, 1912.

Luterbacher, J., Schmutz, C., Gyalistras, D., Xoplaki, E., and Wanner, H.: Reconstruction of monthly NAO and EU indices back to AD 1675, Geophys. Res. Lett., 26, 2745-2748, 1999.

Luterbacher, J., Xoplaki, E., Dietrich, D., Jones, P. D., Davies, T. D., Portis, D., Gonzalez-Rouco, J. F., von Storch, H., Gyalistras, D., Casty, C., and Wanner, H.: Extending North Atlantic Oscillation reconstruction back to 1500, Atmos. Sci. Lett., 2, 114-124, 2002.

Meyersson, Å.: Vattendrag och inre farleder i Gustav Vasas Sverige, Föreningen Sveriges Sjöfartsmuseum, Årsbok, 28-39, 1943.
Noraskogs arkiv.: Bergshistoriska samlingar och anteckningar, Bd. 1, Stockholm, 1889-1891.

Norberg, P.: Avesta under kopparbrukets tid, Del. 1, Stockholm, 1956.

Norberg, P.: Gästriklands hyttor och hamrar, Blad för bergshanteringens vänner, 33, 193-475, 1958-1959.

Nordenström, M. N.: Utkast till beskrifning öfwer Stöde socken vid Medelpads södra ådal belägen, C. E. Fritze, Stockholm, 1894.

Ny journal uti hushållningen: Stockholm, 1776-1813.

Odelman, E. and Melefors, E. (Eds.): Visbyfranciskanernas bok: Handskriften B 99 i Kungliga biblioteket, Visby, 2008.

Olofsson, S. I, and Liedgren, J.: Övre Norrlands historia, Del. 3, Tiden 1638-1772, Umeå, 1974.

Olofsson, S. I. and Stille, A.: Övre Norrlands historia, Del. 2, Tiden 1600-1721, Umeå, 1965.

Österberg, E.: Gränsbygd under krig: Ekonomiska, demografiska och administrativa förhållanden i sydvästra Sverige under och efter nordiska sjuårskriget, Gleerups, Lund, 1971.

Palme, S. U.: Sverige och Danmark 1596-1611, Almqvist \& Wiksell, Uppsala, 1942.

Paulsson, G. (Ed.): Annales Suecici medii ævi: Svensk medeltidsannalistik, Gleerup, Lund, 1974.

Pfister, C.: Wetternachhersage, 500 Jahre Klimavariationen und Naturkatastrophen (1496-1995), Paul Haupt, Bern, 1999.

Prudhomme, C. and Genevier, M.: Can atmospheric circulation be linked to flooding in Europe?, Hydrol. Process., 25, 1180-1190, 2011.

Rääf, L. F.: Samlingar och anteckningar till en beskrifning öfver Ydre härad i Östergöthland, Del. 5, Ydre härads i Östergöthland sjöar, vägar, fornminnen m m, Linköping, 1875.

Retsö, D.: A contribution to the history of european winters: some climatological proxy data from early 16th century Swedish documentary sources, Climatic Change, 52, 137-173, 2002.

Retsö, D. and Söderberg, J.: Climatological data in documentary sources for medieval Sweden: an overview, in preparation, 2015a.

Retsö, D. and Söderberg, J.: Weather and climate in Sweden in the Middle Ages, in preparation, 2015b.

Riksarkivet - Swedish National Archives: Bergskollegium, huvudarkivet, Bergverksrelationer EII:a.

Riksarkivet - Swedish National Archives: Kammararkivet, Bergsbruk, Sala gruva, 1533-1537.

Riksarkivet - Swedish National Archives: Landshövdingens i Uppsala län skrivelser till K. M.:t, arkivförteckning.

Riksarkivet - Swedish National Archives: Medieval codex A 21.

Riksarkivet - Swedish National Archives: Riksregistraturet 1569, 1572, 1587, 1588, 1639.

Ringborg, E.: Till Norrköpingskrönikan, Vol. 3, Norrköping, 1920.

Rohr, C.: Extreme Natureignisse im Ostalpenraum, Naturerfahrung im Spätmittelalter und am Beginn der Neuzeit, Böhlau Verlag, Köln, Weimar, Wien, 2007

Rokoengen, K., Norman Jespersen, M., Kleiv, R. A., and Sæterbøe, E.: The 1345 slide and flood disaster in the Gauldalen valley, Mid-Norway: a new interpretation, Norsk Geogr. Tidsskr., 55, 57-70, 2001.

Rørdam, H. (Ed.): Historiske kildeskrifter og bearbejdelser af dansk historie især fra det 16. aarhundrede, Vol. 1, Monumenta historiæ danicæ, København, 1873. 
Rydberg, G.: Fornåsaprästen och syndafloden, ÖGF-lövet, February 1997.

Schmocker-Fackel, P. and Naef, F.: Changes in flood frequencies in Switzerland since 1500, Hydrol. Earth Syst. Sci., 14, 1581-1594, doi:10.5194/hess-14-1581-2010, 2010.

Sillén, A. W.: af: Svenska näringarnes och handelns historia, Del. 4 , Under Wasaätten, Stockholm, 1865.

Silvén-Garnert, E. and Söderlind, I. (Eds.): Ett annat Sverige: Dokument om folkets kamp 1200-1720, LT, Stockholm, 1980.

Sjöberg, N. (Ed.): Johan Ekeblads bref, Del. 1, Från Kristinas och Cromwells hof, Norstedt, Stockholm, 1911.

Sjöberg, N. (Ed.): Johan Ekeblads bref, Del. 2, Från Karl X:s fälttåg samt lifvet i hufvudstaden, Norstedt, Stockholm, 1915.

Sjödin, L. (Ed.): Gamla papper angående Mora socken, Vol. 2, Arvid Siggessons brevväxling, Västerås, 1937.

Sommarström, H.: Finland under striderna mellan Sigismund och hertig Karl, Del. 1, Klas Flemings tid, Björck och Börjesson, Stockholm, 1935.

Stille, A.: Kriget i Skåne 1709-1710, Militärlitteraturföreningens förlag, Stockholm, 1903.

Strelow, H. N.: Cronica Guthilandorum: Den guthilandiske cronica, Kiøbinghaffn, 1633.

Strömbeck, G. (Ed.): Herr Mårten i Borgby eller Martinus Laurentii Aschaneus som kyrkoherde i Fresta och Hammarby 1620-1641: Dokumentarisk sammanställning, Upplands Väsby, 1993.

Sturm, K., Glaser, R., Jacobeit, J., Deutsch, M., Brázdil, R., and Pfister, C.: Hochwasser im Mitteleuropa seit 1500 und ihre Beziehung zur atmosphärischen Zirkulation, Petermanns Geogr. Mitt., 145, 18-27, 2001.

Styffe, C. G. (Ed.): Bidrag till Skandinaviens historia ur utländska arkiver, Del. 3, Sverige under Karl Knutsson och Kristiern af Oldenburg, 1448-1470, Norstedt, Stockholm, 1870

Styffe, C. G. (Ed.): Rikskansleren Axel Oxenstiernas skrifter och brefvexling, Afd. 2, Bd. 5, Jacob de la Gardies bref 1611-1650, Kungl. Vitterhets historie och antikvitets akademien, Stockholm, 1893.

Swederus, M. B.: Bidrag till kännedomen om Sveriges bergshandtering 1612-1654, Del. 2, Stockholm, 1911.
Sylvius, J.: The swenskes och göthers historia, skrefwen på latin aff Erico Olai, Stockholm, 1678.

Tigerstedt, K. K. (Ed.): Ur Per Brahes Brefväxling: Bref från och till Per Brahe, Del. 2, Samson \& Wallin, Stockholm, 1888.

Tilander, G. (Ed.): Nyköpingsstudenten Johannes Julinus dagböcker 1659-64 och hans bedrifter i Uppsala, Åbo och Strängnäs, Skara, 1968

Utterström, G.: Climatic fluctuations and population problems in early modern history, Scand. Econ. Hist. Rev., 3, 39-79, 1955.

Utterström, G.: Jordbrukets arbetare: Levnadsvillkor och arbetsliv på landsbygden från frihetstiden till mitten av 1800-talet, Del. 2, Tiden, Stockholm, 1957.

Uvo, C. B.: Analysis and regionalization of northern European winter precipitation based on its relationship with the North Atlantic Oscillation, Int. J. Climatol., 23, 1185-1194, 2003.

von Dalin, O.: Svea rikes historia ifrån des begynnelse til wåra tider ..., Del. 3:1, Stockholm, 1760-1761.

von der Ropp, G. (Ed.): Hanserecesse, Abt. 2, Von 1431-1476, Bd. 4, Duncker \& Humblot, Leipzig, 1883.

Waaranen, J. E. (Ed.): Handlingar upplysande Finlands historia under Karl IX:s tid, Del. 2, 1603-1608, Helsingfors, 1864.

Wallén, A.: Vänerns vattenståndsvariationer, Stockholm, 1910.

Wennberg, A.: Lantbebyggelsen i nordöstra Östergötland 1600 1875, Gleerups, Lund, 1947.

Wetter, O., Pfister, C., Weingartner, R., Luterbacher, J., Reist, T., and Trösch, J.: The largest floods in the High Rhine basin since 1268 assessed from documentary and instrumental evidence, Hydrolog. Sci. J., 56, 733-758, 2011.

Wijkmark, C. (Ed.): Allrakäraste: Catharina Wallenstedts brev 1672-1718, Atlantis, Stockholm, 1995.

Wik, H.: Norra Sveriges sågverksindustri från 1800 - talets mitt fram till 1937, Uppsala, 1950.

Wittrock, G.: Svenska handelskompaniet och kopparhandeln under Gustaf II Adolf, Almqvist \& Wiksell, Uppsala, 1919.

Wittrock, G.: Regering och allmoge under Kristinas förmyndare: Studier rörande allmogens besvär, Skrifter utgivna av K. Humanistiska vetenskapssamfundet i Uppsala, Uppsala, 1948.

Wolontis, J.: Kopparmyntningen i Sverige 1624-1714, Lund, 1936 